This item was submitted to Loughborough's Research Repository by the author.

Items in Figshare are protected by copyright, with all rights reserved, unless otherwise indicated.

\title{
Measuring poverty using both income and wealth: A cross-country comparison between the U.S. and Spain
}

PLEASE CITE THE PUBLISHED VERSION

https://doi.org/10.1111/j.1475-4991.2011.00481.x

\section{PUBLISHER}

(C) 2011 The Author ( 2011 International Association for Research in Income and Wealth. Published by Wiley

\section{VERSION}

AM (Accepted Manuscript)

\section{PUBLISHER STATEMENT}

This work is made available according to the conditions of the Creative Commons Attribution-NonCommercialNoDerivatives 4.0 International (CC BY-NC-ND 4.0) licence. Full details of this licence are available at: https://creativecommons.org/licenses/by-nc-nd/4.0/

\section{LICENCE}

CC BY-NC-ND 4.0

\section{REPOSITORY RECORD}

Azpitarte, Francisco. 2019. "Measuring Poverty Using Both Income and Wealth: A Cross-country Comparison Between the U.S. And Spain". figshare. https://hdl.handle.net/2134/36507. 


\title{
Measuring Poverty using both Income and Wealth: A Cross-Country Comparison between the U.S. and Spain
}

\author{
Francisco Azpitarte ${ }^{* \dagger}$ \\ Melbourne Institute of Applied Economics and Social Research \\ \& Brotherhood of St Laurence
}

\begin{abstract}
We study the correspondence between a household's income and its vulnerability to income shocks in two developed countries: the U.S. and Spain. Vulnerability is measured by the availability of wealth to smooth consumption in a multidimensional approach to poverty, which allows us to identify three groups of households: the twice-poor group which includes income-poor households who lack of an adequate stock of wealth; the group of protected-poor households, which are all those incomepoor families with a buffer stock of wealth they can rely on; lastly, the vulnerablenon-poor group, including households above the income-poverty line that do not hold any stock of wealth. Interestingly, the risk of belonging to these groups changes over the life-cycle in both countries while the size of the groups differs significantly between Spain and the U.S., although this result is quite sensitive to whether the housing wealth component is included in the wealth measure or not.
\end{abstract}

Keywords: Income poverty, wealth, vulnerability.

JEL Classification: D14, D31

\footnotetext{
*Correspondence to: Francisco Azpitarte, Melbourne Institute of Applied Economics and Social Research, University of Melbourne, Victoria 3010, Australia (fraz@unimelb.edu.au).

${ }^{\dagger}$ Financial support from the Xunta de Galicia (10SEC300023PR), the Ministerio de Ciencia e Innovación (ECO2010-21668-C03-03), and the Pedro Barrié de la Maza Foundation is gratefully acknowledged.
} 


\section{Introduction}

The definition of poverty and the identification of the poor is a complex issue. To date the main focus of poverty measurement has been on income flows. Indeed, most official statistics in industrialized countries use data on monthly or yearly household income to determine the incidence of the poor. However, income-poverty indicators may provide limited information on household economic welfare. An important result derived from income based poverty studies is that there exists a large low income turnover, with a significant number of households falling below the income threshold and experiencing low income spells (Jarvis and Jenkins, 1998). If this is the case, it is clear that income flows are not fully informative about families' vulnerability to income shocks as they do not provide information on the capacity households have for sustaining a minimum standard of living during low income periods. Consequently, if one believes household vulnerability is relevant to identify those individuals with low economic welfare, then standard income measures should be supplemented with information on other households' attributes.

Among the many determinants of welfare, wealth is central to the vulnerability of households in times of economic crisis. Wealth holdings constitute the main instrument households have to insure themselves against risk as they importantly determine the extent to which families can smooth consumption in periods of low income. In fact, assets contribute to the economic security of families as they can be converted directly into cash or can be used as collateral in order to provide liquidity. Therefore, the joint analysis of income and wealth will clearly contribute to improve our knowledge about households' well-being, allowing us to study the correspondence between households' current income and their vulnerability to income shocks, measured by the availability of wealth type resources for maintaining consumption during an income-poverty spell.

The main aim of this paper is to measure and characterize poverty using both income and wealth, and to compare these results with those derived from the standard income-poverty approach. To this purpose, we quantify and identify poor households in two industrialized countries: the U.S. and Spain. ${ }^{1}$ We argue the comparison of these two countries is relevant for several reasons. First, the U.S. and Spain are both characterized by a welfare model typically catalogued as rather weak compared to that found in Nordic countries (Esping-Andersen, 2002). The measurement of vulnerability using

\footnotetext{
${ }^{1}$ To the best of our knowledge, our work is the first attempt to perform a comparative poverty analysis of these two countries using both income and wealth. The contribution of assets to families' welfare has received less attention in Spain than in the case of the U.S., mainly due to the fact that until 2002, there was an absolute lack of adequate data for undertaking this type of research.
} 
wealth holdings is especially interesting in this context given the greater importance of assets as insurance mechanism in a low social protection situation. Also, given the existing evidence showing a higher incidence of relative income-poverty in the U.S. than in Spain (OECD, 2008), we argue it is interesting to know whether this poverty ordering still holds when income and wealth are analyzed together. Further, Spain and the U.S. exhibit important differences in the demographic structure and the household formation process (Bover 2010, Reher 2008), with Spain showing a larger share of young people living with their parents, which might have important consequences on saving behavior and the relationship between income and wealth over the life cycle.

Differently to recent attempts in the literature, we propose a multidimensional approach where a poverty line is specified for each dimension, so that the levels of deprivation in income and wealth can be determined separately. ${ }^{2}$ This allows us to distinguish three groups of poor households. Within the twice-poor group, we would include those households in poverty who also lack an adequate stock of wealth, and therefore may be trapped in a low-welfare situation where they are unable to build-up financial assets given their current income flows. Secondly, the group of protected-poor would refer to all those families whose income is below the income-poverty threshold, but who have some capacity to cope with related liquidity problems, since they hold a buffer stock of wealth resources they can rely on. Lastly, the vulnerable-non poor group would include every household above the income-poverty line who, even if out of poverty, does not have a stock of economic resources that enables its members to smooth consumption in the absence of income flows, and this may push them into economic deprivation in times of economic crisis. ${ }^{3}$

Interestingly, we find that poor groups are very heterogeneous among them, so that the poverty profile derived from the multidimensional analysis is, in general, quite different to the income-poverty profile. Also, similarly to the case of income, the poverty rate in the U.S. is greater than in Spain when poverty is measured using both income and wealth. In fact, there exists a large gap between the two countries, especially in the

\footnotetext{
${ }^{2}$ Previous literature aimed to measure poverty using income and wealth mostly apply the annuity method proposed by Weisbrod and Hansen (1968) to summarize the information on both dimensions into a single index of welfare (Brandolini et al., 2010, Zagorsky, 2006, Short and Ruggles, 2006, Van den Bosch, 1998). However, due to the aggregation of information, this approach does not allow us to study the vulnerability of households independently of their current income situation, which is part of the motivation of this paper.

${ }^{3}$ This is precisely the approach used by Wolff (1990) and Radner and Vaughan (1987) to measure poverty in the U.S. Our paper differentiates from these works as we quantify and characterize the different groups of poor households, while these authors applied this methodology only to measure the proportion of twice-poor households.
} 
case of the twice-poor and vulnerable-non poor, whose presence in the U.S. more than doubles that in Spain. We ask whether this differential may be attributed to differences in the household structure. As Bover (2010) recently shows, household demographics account for a large share of the differences at the bottom of the wealth distributions in the U.S. and Spain. Azpitarte (2011) compares the extent of asset-poverty in the U.K. and Spain using different poverty definitions and wealth thresholds. Using counterfactual distribution analysis, this author finds that differences in the distribution of households explains little of the wealth-poverty gap between these two countries no matter where one draws the poverty line. Drawing on the methods adopted in these articles, the present paper contributes to the existing literature by comparing the characteristics of poverty in the U.S. and Spain using information on both income and wealth. Differently to early contributions, this allows us to study the relationship between income flows and wealth holdings and how it influences the incidence of vulnerable households in these two countries. Furthermore, we use a multidimensional variant of the counterfactual approach proposed by Bover (2010) to assess the contribution of household demographics to explain the difference in the number of vulnerable households in the U.S. and Spain. Our results suggest that variations in the household structure contribute to explain the larger incidence of poor groups in the U.S., particularly in the case of the vulnerablenon poor, where this factor accounts for more than three quarters of the gap. Note, however, that there remains an important part of the difference that is not explained by the demographic structure.

The paper is organized as follows. In Section 2, we present the data sources we use in the analysis. Section 3 describes the income sources and the portfolio composition, as well as, the relationship between income and wealth in Spain and the U.S. Section 4 includes the main results of the paper on income and income-and-wealth poverty. First, we report the incidence and characterization of poor households in Spain and the U.S. Also in this section, we summarize the main differences between the household structures of these two countries. We complete this section presenting the results of the counterfactual decomposition analysis. Finally, in Section 5 we detail our main conclusions.

\section{Data Sources and Methods}

In this paper we rely on data from two highly comparable wealth surveys in the Spain and the U.S. In particular, the data for the U.S. is from the 2001 Survey of Consumer Finances 
$(\mathrm{SCF}),{ }^{4}$ whereas for Spain we use the information in the first wave of the Spanish Survey of Household Finances (Encuesta Financiera de las Familias, EFF) conducted in 2002. ${ }^{5}$ Both the SCF and the EFF are aimed at providing detailed information about the assets and liabilities held by households, as well as data on employment, income, and other demographic characteristics of the households in the U.S. and Spain, respectively. Thus, the 2001 SCF provides all this information for a sample with more than 4,000 households, while the first wave of the EFF includes a sample with more than 5,000 households.

Importantly, the information provided in the SCF and the EFF is rather homogeneous, which allows a high degree of comparability between the U.S. and Spain. With regard to the data on income, both the EFF and the SCF contain information on the different sources of income. In particular, in this paper we will use the annual household gross income (before taxes and contributions to the Social Security System). ${ }^{6}$ This variable is the sum of wages and salaries, self-employment earnings, capital income, unemployment benefits, private and public retirement pensions, and other transfers received by any household member. ${ }^{7}$ In the case of wealth, in both the EFF and the SCF, households are asked to report the value of a wide range of tangible and financial assets as well as the household's outstanding debts at the moment of the interview. ${ }^{8}$ In particular, the two surveys contain information about the ownership status and the value of the main residence and other real estate properties, as well as the amount pending repayment of the

\footnotetext{
${ }^{4}$ We use the data from the 2001 SCF included in the Luxembourg Wealth Study (LWS) database. The LWS is an international project launched in 2003, whose primary goal is to harmonize existing microdata on wealth. At present, Austria, Canada, Cyprus, Finland, Germany, Italy, Norway, Sweden, United States and United Kingdom are contributing with their national data sets. A complete description of the LWS database can be found in http://www.lisproject.org.

${ }^{5}$ For a detailed description of the methodology used in the first wave of the EFF, see Bover (2004).

${ }^{6}$ In both surveys households are asked to report the income perceived during the year previous to the survey. Thus, income data for Spain correspond to 2001, while for the U.S. it measures the income households received in 2000. We decided to use a gross measure of income because the Spanish survey does not include any income measure net of taxes and contributions to the Social Security System.

${ }^{7}$ Notice that the use of gross income is consistent with the U.S. official poverty definition of poverty. As one of the referees rightly pointed out, the use of this measure may be inconsistent with the treatment of wealth, as it is gross of interests paid on debts, and also because it does not include the imputed rent on owner-occupied dwellings. Note, however, that this is the standard measure of income commonly applied in income-poverty analysis. Given our interest in assessing the effect of departing from the traditional income-poverty definition, we argue it is reasonable to use the standard measure of income.

${ }^{8}$ A complete description of the information on wealth holdings in the SCF 2001 and the EFF 2002 is included in the appendix. In particular, the interviews for the Spanish survey were performed between October 2002 and May 2003, whereas in the case of the SCF, the information was collected during the second half of 2001.
} 
loans related to the purchase of these assets. The EFF and the SCF also provide us with the value of the businesses owned by any household member, as well as, the value of the means of transport, jewelry, works of art, antiques and other non-financial assets held by the household. ${ }^{9}$ Regarding the financial portfolio, both surveys include information on the value of all deposits and accounts in financial institutions, stocks, mutual and investment funds, bonds, pension plans, ${ }^{10}$ life insurance and other financial assets (such as loans to third parties) owned by household members. Finally, the EFF and the SCF also contain information on debts not related to the purchase of real estate properties, including its type, motive and amount pending repayment of the loans held by the household. All this information allows us to construct a broad net worth measure for Spanish and U.S. households, which is defined as the total value of real and financial assets minus the current value of debts. Real assets are defined as the sum of the gross value of owneroccupied housing, other real estate, business equities related to self-employment, vehicles, jewelry, works of art and other non-financial assets. ${ }^{11}$ Financial assets include the current value of transaction and saving accounts, total bonds, stocks, mutual and investment funds, private pension schemes, life insurance, and other financial assets. Finally, the value of total debt is the sum of principal residence debt, other real estate debt, vehicle and educational loans, and other debts. ${ }^{12}$

Additionally, the EFF and the SCF share relevant methodology features that make them especially suitable for comparative analysis. ${ }^{13}$ Indeed, an important characteristic of these two samples is the over-sampling of wealthy households. ${ }^{14}$ As Davies and Shorrocks (2000) suggest, this is a necessary condition in order to obtain an accurate picture of aggregate wealth, given that an important share of total assets belongs to the richest households. Notice that, despite the over-sampling of the rich, the representativeness of the two samples is guaranteed by the use of appropriate sample weights. Another common

\footnotetext{
${ }^{9}$ The value of all real assets corresponds to a self-assessed value reported by the head of the household at the moment of the interview.

${ }^{10}$ The entitlements to Social Security pensions are not included in this category, given that households are asked to report only the present value of the private pension plans.

${ }^{11}$ This category includes the value of gold, silver, antiques, stamp collections, and other collectibles in the household.

${ }^{12}$ This category includes the value of installment debt, other loans from financial institutions, and informal debt.

${ }^{13}$ Indeed, the EFF was constructed following the model of the SCF (Bover, 2004).

${ }^{14}$ Over-sampling in the EFF is based on the individual information of the Spanish wealth tax (Impuesto sobre el Patrimonio), while in the SCF it is based on a supplementary high-income sample drawn from income tax records. For more information on these two procedures, see Bover (2004) and Kennickell (2008).
} 
feature in the $\mathrm{EFF}$ and in the $\mathrm{SCF}$ is that both surveys use the same imputation method to provide complete information on households' income and wealth holdings even if a household fails to respond to the complete questionnaire. ${ }^{15}$

The unit of analysis we use in this paper is the household. In both surveys, a household is defined as including all individuals living together in the same dwelling, but additional requirements are considered in each survey. In the case of Spain, sharing expenses is a condition to form a household, while in the U.S., financial interdependence with the economically dominant person or couple is required. Lastly, as it is usual in regular income poverty analysis, we convert income to equivalent income taking into account the differences in needs across households due to the economies of scale in consumption. ${ }^{16}$ In the case of wealth, since we are interested in the ability of families to overcome times of economic crisis using accumulated wealth holdings, we also consider differences in needs across households when measuring wealth. ${ }^{17}$ Thus, we compute the equivalent values of both income and wealth variables using a consistent single parameter scale with a square-root-of-household-size scale factor. In particular, adjusted variables are equal to unadjusted variables divided by household size raised to an exponential value equal to $0.5 .^{18}$

\section{Income and Wealth in the U.S. and Spain}

\subsection{Income Sources and the Wealth Portfolio}

Before undertaking the poverty analysis, in this section we study separately the income and wealth dimensions of welfare. For this purpose, we look first at the income sources and the asset portfolio composition of households in the U.S. and Spain. As Table 1 shows, there exist important differences regarding the income sources of Spanish and U.S. households. Labour earnings have a greater importance in the U.S. than in Spain. Indeed,

\footnotetext{
${ }^{15}$ The imputation method is the Federal Reserve Imputation Technique Zeta (Fritz). This is a stochastic method with a sequential and iterative structure. For more details, see Kennickell (1998 and 2000).

${ }^{16}$ For a comparative survey of income poverty and equivalence scales see Jäntti and Danziger (2000).

${ }^{17}$ In contrast with income distribution analysis, in the case of wealth there is no standard approach to account for different needs across households. In a recent discussion on the use of equivalence scales in wealth distribution analysis, Sierminska and Smeeding (2005) show that measures of wealth inequality are sensitive to equivalence scales, decreasing when higher economics of scale are assumed.

${ }^{18}$ This is a particular case of the family of equivalence scales proposed by Buhmann et al.(1988) widely used in regular inequality and poverty analysis, where household needs are equal to $S^{\theta}$, where $S$ is the size of the household and $\theta$ is the elasticity of the scale rate, which in our case is set equal to 0.5.
} 
the proportion of households where none of the members is an active earner in the U.S. is nine points lower than in Spain, where this type of households represents about 29 percent of the population ${ }^{19}$. Instead, Spanish households have a larger dependence on the income from pensions and transfers than their U.S. counterparts: more than 48 percent of Spanish households perceived some income from transfers or pension plans, while in the U.S. this percentage was below 40 percent, which explains the larger importance of this income source in total income in Spain compared with the U.S. (19 and 9 percent).

\section{[Place Table 1 here]}

In the case of wealth, the results in Table 2 highlight important differences in the portfolio composition of Spain and the U.S. Thus, as it has been already documented in the literature, Spain exhibits a large preference for less-liquid assets, especially for housing wealth, while the U.S. households show a significantly higher share of financial wealth (Bover et al., 2005). Almost 82 percent of Spanish households own their main residence, and more than 30 percent own some other real estate, whereas in the U.S. these figures are around 68 and 16 percent, respectively. In fact, Spain presents the largest proportion of homeowners among OECD countries, where this proportion ranges from the 40 percent observed for Germany to the 80 percent observed for Spain, Greece, and Italy (Christensen et al. 2005). Consequently, real assets have a significantly larger importance in Spain, accounting for almost 87 percent of total assets, while in the U.S.

[Place Table 2 here]

they represent 58 percent. Clearly, the other side of the coin is that U.S. households reveal a larger preference for more liquid assets in comparison with Spanish households. Indeed, for every financial asset except for deposit accounts, the rate of ownership in the U.S. is larger than in Spain. For instance, only 12 percent of the Spanish households hold some type of share, while in the U.S., this proportion is about 21 percent. If compared with other countries included in the LWS, the figure for Spain is similar to that of another Mediterranean country like Italy, where the number of shareholders is around 11 percent.

\footnotetext{
${ }^{19}$ Differences in the demographic structure of the two countries contribute to explain this result. Thus, as we show in Section 4, the proportion of households headed by individuals above 65 in Spain is significantly greater than in the U.S.
} 
Meanwhile, the rate of ownership in the U.S. is more similar to that observed for the United Kingdom, and Nordic countries like Norway and Sweden, where the number of owners is about 30 percent. The low presence of financial assets in the Spanish households' portfolio explains the lower weight of financial assets have within total wealth compared with the U.S. (about 12 versus 42 percent). Finally, regarding the debt component, more than 75 percent of households in the U.S. hold some type of debt, compared with only 43 percent in Spain. Interestingly, despite the larger proportion of homeowners observed in Spain, the share of households that accumulate debt for this motive in the U.S. is more than twice the level in Spain (43 versus 21 percent).

\subsection{The Relationship between Income and Wealth Holdings}

Income and wealth are both essential in determining the economic well-being and ill-being of individuals (Headey and Wooden 2005, 2004). Therefore, the analysis of the correspondence between income and wealth is central in order to understand the distribution of economic resources and welfare in any society. Indeed, a high correlation between income and wealth indicates a close association between an individual's current and past economic position in society, which may be interpreted as a signal of unequal opportunities and large permanent inequality. In the case of Spain and the U.S., the figures shown in Table 3 suggest a positive correlation between income and wealth in both countries. However, the association between these two variables in the U.S. is markedly larger than in Spain, as suggested by the difference in the values of the correlation coefficient ( 0.5 versus 0.18 ). This difference is mainly attributable to the non-housing component of wealth, since the correlation between this component and income in the U.S. is more than three times that in Spain, whereas the association between income and housing wealth is similar in the two countries. Furthermore, the larger correlation found in the U.S. for the entire population is also observed within race groups, which means that factors other than the race need to be considered in order to explain the large association between income and wealth in this country. ${ }^{20}$ Moreover, the results for housing wealth suggest that the association of this wealth component with other assets is significantly lower in Spain than in the U.S. Indeed, the correlation of the housing component with total net worth and non-housing wealth in Spain is about 0.2 and 0.11 , whereas in the U.S. these figures are around 0.5 and 0.4 , respectively.

\footnotetext{
${ }^{20}$ This result for the U.S. is similar to that found for this country by Budria et al. (2002). These authors report that the correlation coefficient between income and wealth in the U.S. in 1998 was equal to 0.6 .
} 
The results regarding the correlation between income and wealth are confirmed by the lower re-ranking between the two distributions in the U.S. compared with Spain, as shown by the transition matrices based on the quartile distributions of income and net worth presented in Table 9. Information in each matrix is synthesized with the diagonal index $M(P)$ proposed by Shorrocks (1978) (0.9 for Spain, 0.83 for the U.S.). The figures indicate a larger upward mobility in Spain, where about 33 and 32 percent of the households in the bottom quartile of income and wealth, respectively, are in the third or fourth quartile of the other dimension when there is re-ranking, compared with 24 and 17 percent in the U.S. Consistent with this result, we find that the U.S. presents a greater correspondence at the bottom and the top of the distributions: 52 and 55 percent of U.S. households in the bottom and top quartile of income, respectively, remain in the same quartile of net worth after re-ranking, compared with 39 and 47 percent in Spain. ${ }^{21}$ Jäntti et al. (2008) described the quartile distribution of income and wealth in the U.S., Canada, Italy, and Sweden using information in the LWS database, and they found that within this group of countries, the U.S. has the highest concentration of population in the bottom and the top income-wealth quartile groups. Our figures for Spain are similar to those reported by these authors for Italy and Canada, while their results for Sweden show that the correspondence at the bottom of the distributions in this country is lower than in Spain, given that less than 30 percent of Swedish households at the bottom quartile of income are also in the same quartile of wealth. Lastly, the different association between income and wealth found for Spain and the U.S. already indicates that we should expect the financial situation of income-poor households will be quite different in these two countries. ${ }^{22}$ In particular, the results at the bottom of Table 3 show that the difference in wealth holdings between the households below and above the income-poverty line in Spain is significantly smaller than in the U.S. In fact, the average value of non-housing and housing wealth of the income-poor in Spain accounts for about 26 and 62 percent of those above the income-poverty threshold, while in the U.S. they represent 13 and less than 32 percent, respectively.

[Place Table 3 here]

\footnotetext{
${ }^{21}$ Our results for the U.S. are similar to those found by Radner and Vaughan (1987). These authors computed a transition matrix for U.S. using data for 1979, and they reported a value of the mobility index equal to 0.85 .

${ }^{22}$ Income-poor households are defined as those whose income is below 50 percent of the median equivalent household income. A detailed discussion on poverty thresholds is presented in the next section.
} 


\section{Poverty Analysis}

\subsection{The Poverty Approach}

The main goal of this section is to characterize poverty in Spain and the U.S. looking at income and wealth, and to compare the results with those obtained from the standard income-poverty approach. In the case of income-poverty, the official methods used to identify income-poor households in these two countries differ regarding various methodological issues. ${ }^{23}$ In particular, income-poverty measurement in the U.S. is based on a set of absolute income-poverty thresholds aimed to reflect the basic cost of living in this country, which vary according to the size and composition of the family. However, in Spain, as in other E.U. countries, a relative notion of income-poverty is adopted in the so called "Laeken" indicators of poverty, which are computed using an income-poverty line equal to 60 percent of the median income. For the sake of comparability, in this paper we will follow a relative approach to measuring income-poverty in Spain and the U.S. In order to check for the sensitivity of results to a particular choice of threshold, we use three different income thresholds that correspond to the 40, 50, and 60 percent of the median income. $^{24}$

A relevant issue that needs to be faced when taking a multidimensional approach to poverty is how to integrate the different dimensions (Silber, 2007). In the case of income and wealth, two alternative approaches have been proposed in the literature. In the first approach, the annuity method is used to aggregate the two variables into a single indicator of welfare, converting household net worth into a flow of resources, such that, every household whose annuity from wealth is not enough to compensate the income poverty gap is considered as poor (Zagorsky 2006, Short and Ruggles 2006, Van den Bosch 1998, Wolff 1990, Weisbrod and Hansen 1968). Alternatively, in the second approach a poverty line is specified for each dimension, identifying as poor all those households that have an insufficiency in either income or wealth (Wolff 1990, Radner and Vaughan 1987). We argue that this method implies a more efficient use of the information on income and wealth than the annuity method, as it allows us to measure the vulnerability of households to negative income shocks independently of their current position in the income distribution, which enables a better description of the different poverty status.

\footnotetext{
${ }^{23}$ For an excellent discussion of the official methods used to measure income-poverty in the U.S. and in E.U. countries, see Notten and Neubourg (2007).

${ }^{24}$ Jesuit and Smeeding (2002) show that the U.S. absolute poverty line is close to the 40 percent threshold.
} 
Indeed, this methodology, in contrast with the annuity approach, permits to characterize vulnerable-non poor households, that is, households whose incomes are above the poverty line but that hold few assets, which makes them vulnerable if current income were to be reduced or to cease entirely. In addition, it also allows us to identify protected-poor, as well as, twice-poor households, where the former refers to households with incomes below the income threshold but with sufficient wealth holdings to maintain a minimum standard of living, whereas the second category includes all the households that are deprived in both dimensions.

In order to characterize the different groups of poor households a definition of wealthpoverty is required. Following Caner and Wolff (2004), we identify asset-poverty with the lack of enough asset holdings to overcome periods of economic crisis with low income flows. Thus, to determine the asset-poverty status we will compare households' wealth with some threshold value reflecting a minimum welfare level required to be maintained by means of wealth holdings (Caner and Wolff 2004, Hubbard et al. 1995). In particular, we define the wealth-poverty threshold as a function of the relative annual income poverty line used to measure income poverty. This option slightly differs from that used by Caner and Wolff (2004) to quantify asset-poverty in the U.S., as they use a family-size conditioned minimum consumption threshold aimed to reflect the cost of satisfying basic needs. However, given the difficulty for constructing a comparable measure of basic needs for Spain, and given our interest in measuring the capacity of Spanish and U.S. households to overcome periods of income-poverty, we argue that the use of the income threshold as wealth-poverty line is especially suitable for comparing the incidence of asset-poverty in these two countries. ${ }^{25}$ Furthermore, in order to check the robustness of the results, we propose three wealth-poverty lines that result from dividing the income threshold by 12 , 4 , or 2, where the idea is to check if the household could support itself with wealth holdings at the income-poverty line for one, three, or six months, respectively. Lastly, the variable we use to measure the incidence of asset-poverty is the equivalent net worth defined in Section 2. In addition, we compute the poverty rates considering only the

\footnotetext{
${ }^{25}$ Our option also differs from that adopted by Hubbard et al. (1995) to analyze the relationship between asset-based, means-tested social welfare programs and the number of low-wealth households in the U.S. In particular, these authors use a household-specific wealth threshold that depends on household income, such that, every household with net-worth less than their annual current income is identified as asset-poor. An important drawback of this methodology is that it is possible that households with low wealth holdings may not be considered as asset-poor if they also have low income, while households with a large amount of wealth may be identified as wealth-poor simply because their wealth is relatively low compared with their income.
} 
non-housing wealth component, which is equal to net worth minus the net value of the principal residence.

\subsection{Results}

\subsubsection{Incidence}

Table 4 shows the figures on the extent of income-poverty and the relative size of the three groups of multidimensional poor households in Spain and the U.S. Income-poverty is larger in the U.S. than in Spain regardless of the income threshold considered. For instance, results in the table show that about 23 percent of Spanish households are identified as income-poor with the 60 percent income threshold, while in the U.S. the incidence is around 29 percent. The larger incidence of income-poverty observed in the U.S. relative to other rich countries has been already documented in the literature (Notten and Neubourg 2007, Smeeding 2006, Jäntti and Danziger 2000). This differential in income-poverty rates is larger for lower income-poverty lines. In fact, the number of U.S. households identified as income-poor with the 40 percent income threshold is more than twice that in Spain (17 and 8 percent), while in the cases of the 50 and 60 percent thresholds this proportion is around 1.5 and 1.2 times larger in the U.S. than in Spain, respectively.

Interestingly, we find that the number of households identified as poor when looking at both income and wealth in the U.S. is larger than in Spain whatever the combination of poverty lines. In particular, the most striking difference between these two countries is found for the twice-poor and the vulnerable non-poor groups. Thus, the proportion of households that are identified as poor in both dimensions is significantly greater in the case of the U.S. (between 6 and 14 percent depending on the thresholds considered). ${ }^{26}$ Similarly, the number of vulnerable-non poor households in the U.S. is greater than in Spain for every poverty line. For example, using the 50 percent income-poverty line, we find that the proportion of households that do not hold a minimum amount of wealth even if they are above the income threshold in Spain is between 2 and 7 percent, meanwhile in the U.S. this proportion lies between 4 and 11 percent. In contrast with the other two groups, the proportion of protected-poor households is rather similar in the two countries, even when the housing component is removed. However, the exclusion of this component significantly affects the number of twice-poor and vulnerable-non poor households, espe-

\footnotetext{
${ }^{26}$ Wolff (1990) computed this poverty rate for the U.S. using the official income-poverty line and different wealth percentiles as wealth-poverty thresholds, and he found that between 7 and 11 percent of U.S. households were poor in both dimensions in 1983.
} 
cially in Spain. Indeed, the number of twice-poor households in this country more than doubles when housing is not included and, unlike the case of the net worth, the size of the vulnerable-non poor group becomes larger in Spain than in the U.S.

[Place Table 4 here]

\subsubsection{Identification}

To the purpose of identifying the different groups of poor households, Table 5 presents the incidence of both income and multidimensional poverty by households groups. In addition, to study the effect that different socioeconomic characteristics have on poverty, Table 6 reports the estimates of two alternative probabilistic models for the risk of being identified as poor. ${ }^{27}$ In the case of income-poverty, we use a logit model in which the dependent variable is an income-poverty indicator variable that assigns a value 1 if the household is identified as income-poor, and zero otherwise. For the multidimensional definition of poverty, we propose a multinomial model for the probability of belonging to each of the different groups of poor households. In particular, we estimate a multinomial logit model in which the dependent variable is a discrete variable $y_{i}$ that takes value $1,2,3$, or 4 depending on which of the four groups- twice-poor, protected-poor, vulnerable- non poor, and never-poor- the household belongs to. ${ }^{28}$ Thus, the probability of the household $i$ being included in group $j$ is equal to

$$
p_{i j}=\frac{e^{\left(x_{i}^{\prime} \beta_{j}\right)}}{\sum_{l=1}^{4} e^{\left(x_{i}^{\prime} \beta_{l}\right)}}, \quad j=1, . ., 4, \text { with } \quad \sum_{j=1}^{4} p_{i j}=1
$$

where $x_{i}^{\prime}$ is the set of covariates, and $\beta_{j}$ includes the parameters associated to state $j$ to be estimated. We decide to set the never-poor group as base category so that the

\footnotetext{
${ }^{27}$ Notice that this exercise does not constitute an attempt to provide a casual model for income and asset poverty. Instead, the models are thought to serve simply as a statistical description of the association between the poverty status and households' characteristics, such as the sex, age, educational level, and labour status of the head, as well as other variables regarding living arrangements.

${ }^{28}$ To check the robustness of the results we estimated alternative models that consider different functional forms for the probabilities, such as the multinomial probit, as well as, models that consider two discrete indicator variables $\left(y_{i 1}, y_{i 2}\right)$ for income and wealth poverty, such as the bivariate probit or bivariate logit model. The results of these models, available upon request, are essentially the same that those presented here.
} 
restriction $\beta_{4}=0$ is imposed in order to ensure model identification (Cameron and Trivedi 2005, pp. 500-502). Thus, the parameter $\beta_{j}$ can be interpreted in terms of the relative risk of being in state $j$ rather than in the base group given that

$$
\frac{p_{i j}}{p_{i 4}}=\frac{\operatorname{Pr}\left[y_{i}=j\right]}{\operatorname{Pr}\left[y_{i}=4\right]}=e^{x_{i}^{\prime} \beta_{j}}
$$

Income-poverty rates reported in Table 5 show that the incidence in the U.S. is around twice that of Spain for every age group but those above 65, for which the difference is smaller. ${ }^{29}$ However, the income-poverty profile appears to be rather similar in the two countries. Households at the beginning and at the end of the life cycle are clearly the most over-represented among the income-poor. Also, female headed, single, and lone-parent households are especially vulnerable to income-poverty in both countries. The estimates in Table 6 confirm most of the descriptive results. Young households with heads under 25 years face a greater relative risk of income-poverty, and this effect is larger in the U.S. than in Spain. Instead, old households, particularly those whose head is above 75 years of age, are more exposed to income-poverty only in Spain. Education and inactivity are factors that condition the possibility of income-poverty, especially in the U.S., where the difference in the risk of income-poverty between low and high educated households is particularly large, whereas unemployment implies a greater risk in the case of Spain.

A relevant question is whether a multidimensional poverty approach using income and wealth provides a characterization of poverty different to that based solely on income. Results in Tables 5 indicate that this is precisely the case. In fact, the characteristics of the poor differ importantly across the three groups of poor households defined in terms of income and wealth and, in general, the multidimensional poverty profile is quite different to that derived from income-poverty analysis. Thus, the proportion of twicepoor households is greater among those at early stages of the life-cycle, with households under 35 being clearly over-represented in this group. Moreover, the share of twice-poor households declines with the age of the head, even though the incidence slightly increases among the elderly, especially in the case of Spain. By household type, elder females living

\footnotetext{
${ }^{29}$ We identify the age of the household with the age of the household head. In the EFF the reference person is defined as the person responsible for the accommodation and household finances. In the SCF, for single-person households or households with only one economically dominant person, the head is identified with that person. In households where the economically dominant unit is a couple, the head is taken to be the male in a mixed-sex couple, or the older individual in the case of a same-sex couple.
} 
alone, middle-age singles, especially lone-mother households, as well as, single females under 35 are more likely to be simultaneously income and wealth poor. The estimation results in Table 6 confirm the age profile of the twice-poor group, with households under 35 facing the largest relative risk of being included in this group, while this risk decreases for households who are above 50, even though this reduction is only statistically significant in the case of the U.S. Furthermore, the type of living arrangement highly conditions the chances of being in the twice-poor group: single and lone parent households are the most exposed to this type of poverty in both countries, although people living alone are significantly more vulnerable in the case of the U.S.

Regarding the protected-poor group, the incidence of this group increases with the age of the head, so that households above 65 years of age, who despite of being currently income constrained have accumulated a significant amount of wealth over the life cycle, are clearly the most over-represented in this group. However, the larger relative risk faced by the elderly is only confirmed by the regression results in the case of Spain, as suggested by the value and significance of the dummy variable obtained for this country. Further, we find that two types of households generally identified as vulnerable to income-poverty, such as elder females in single households, usually widows, as well as lone-mother families, have a larger presence in this group: about 40 percent of elder females living alone in Spain and the U.S. are in this situation, whereas the incidence among middle-age lone-mothers is slightly larger in Spain than in the U.S.

On the other hand, both descriptive and estimation results indicate that young households at early stages of the life cycle have the greatest presence in the vulnerable-non poor group. Thus, households under 35 years of age that have not started their wealth accumulation process are the most vulnerable to negative income shocks among those that are above the income threshold. In addition, the incidence of this group clearly declines with the age of the head in both countries, although the share of elderly in this situation is slightly larger in Spain than in the U.S. In fact, similarly to the twice-poor group, the value of the dummies for households above 50 suggests that middle-age and old households have a lower relative risk of belonging to the vulnerable-non poor group in the U.S. than in Spain. Among people under 35, those who are living alone are the most over-represented in the vulnerable-non poor group in both countries, which highlights the financial constraints these type of households may face to accumulate wealth holdings even if they have income levels above the income-poverty line.

Finally, the characterization of the poor groups is slightly modified when only nonhousing wealth is considered. In fact, the figures reported in Tables A.2 and A.3 in 
the appendix, suggest that the number of twice-poor and vulnerable non-poor households increases in all the age groups, especially among middle-age and old households. Moreover, the impact is more significant in the case of Spain, where the proportion of twice-poor and vulnerable-non poor among households above 50 is more than three times larger after eliminating housing wealth. Indeed, the age-profile of these two groups of poor in this country now displays a clear U-shaped pattern, although this pattern is not confirmed by the estimation results. Additionally, the results for Spain show that households headed by elder females are the most affected by the elimination of the home-equity. Thus, the presence of elder females living alone in the twice-poor and the vulnerable non-poor groups increases by a factor of four when the home-equity is removed, which indicates the importance of housing wealth for this type of households.

[Place Table 5 here]

[Place Table 6 here]

\subsection{Accounting for Poverty Differences between Spain and the U.S.}

Results from the previous section suggest that the poverty relevant characteristics are very similar in Spain and the U.S. Indeed, the profile of those households identified as poor when measuring poverty using income and wealth is very similar in these two countries. However, despite this similarity, the incidence of some poor groups in the U.S. is significantly larger than that of Spain, especially in the case of twice-poor and vulnerable-non poor households. This differential may be caused by the different demographic structure in these two countries or by a genuinely larger vulnerability of U.S. households to income and wealth poverty. In order to shed some more light on this issue, our purpose in this section is to quantify the contribution of each of these factors to building this difference.

As suggested by Biewen and Jenkins (2005), to understand differences in poverty rates across countries, it is necessary to separate the influence of the distribution of povertyrelevant characteristics from the influence of the conditional poverty functions. In our case, the comparison of the distribution of poverty-relevant characteristics reveals that most of these characteristics show a similar distribution in the two countries. ${ }^{30}$ However,

\footnotetext{
${ }^{30} \mathrm{~A}$ detailed comparison of the distribution of households by different characteristics in these two countries is presented in the appendix.
} 
as shown in Table 7, important differences exist between Spain and the U.S. regarding age and living arrangements. ${ }^{31}$ Thus, the proportion of households whose head is either under 25 or between 25 and 35 years old is significantly larger in the U.S. than in Spain, whereas the opposite is true for households above 65. Moreover, for all of the age groups considered, the proportion of single and lone-parent households in the U.S. is larger than in Spain. This differential is particularly important for middle-age groups between 25 and 50 years old, where the incidence of singles among U.S. households is more than twice that in Spain. ${ }^{32}$

Importantly, differences in the household structure may clearly contribute to explain the large number of income and wealth poor households found in the U.S. In fact, from the previous section we know that young households at early stages of life cycle, as well as, single and lone parent households are particularly likely to be identified as poor in terms of income and wealth. Consequently, the larger presence of this type of households in the U.S. makes, other things being equal, the household structure of this country more vulnerable than the Spanish one.

\section{[Place Table 7 here]}

Can the household structure explain the difference in the incidence of multidimensional poor groups in Spain and the U.S.? In a recent article, Bover (2010) shows that household demographics account for a large share of the differences in the bottom part of the distribution of wealth observed between Spain and the U.S. We propose a multidimensional version of the approach used by this author in order to estimate the counterfactual poverty rates for the U.S. assuming the characteristics of the Spanish household structure. According to this methodology, the join distribution of income and wealth in the U.S. can be expressed as follows

\footnotetext{
${ }^{31}$ Besides the differences by age and living arrangements, there are important differences regarding educational levels between Spain and the U.S. In fact, the proportion of households headed by a person with low educational attainment is significantly larger in Spain than in the U.S., whereas the proportion of households with a highly educated head in the U.S. is twice that in Spain. However, results not presented here show that controlling for education does not alter the main conclusions on the role of the household structure for explaining the poverty differential between the two countries.

${ }^{32}$ Differences in the household structure between Mediterranean and Anglo-Saxon countries have been already documented. Previous literature points out the existence of two main family models: one with strong family ties, observed in Spain and other Mediterranean countries; and a second with weak family ties, observed mainly in Northern Europe and in the United States. For a discussion on this issue see Reher (1998) and references therein.
} 


$$
F_{U S}(r, t)=E_{U S}[1(Y \leq r, W \leq t)]=E_{U S}\left\{E_{U S}[1(Y \leq r, W \leq t) \mid J]\right\}
$$

where $F(),. E($.$) and 1($.$) denote the distribution, expectation and indicator functions,$ respectively, and $J$ represents the particular set of household types considered for the analysis. Using this notation, the counterfactual U.S. distribution can be easily derived as

$$
\begin{aligned}
F_{U S}^{C}(r, t) & =E_{S P}\left\{E_{U S}[1(Y \leq r, W \leq t) \mid J]\right\}= \\
& =E_{U S}\left[1(Y \leq r, W \leq t) \frac{p_{S P}(J=j)}{p_{U S}(J=j)}\right]
\end{aligned}
$$

where the random variable $\frac{p_{S P}(j)}{p_{U S}(j)}$ is the Radon-Nikodym derivative defined as the ratio of the probabilities of a given household type in Spain and the U.S. To our purpose, this methodology allows us to estimate the U.S. counterfactual poverty rates assuming the Spanish household structure. Thus, for instance, in the case of the twice-poor group, ${ }^{33}$ the size of this group in the U.S. is equal to

$$
P_{U S}\left(z_{Y}^{U S}, z_{W}^{U S}\right)=F_{U S}\left(z_{Y}^{U S}, z_{W}^{U S}\right)=E_{U S}\left\{E_{U S}\left[1\left(Y \leq z_{Y}^{U S}, W \leq z_{W}^{U S}\right) \mid J\right]\right\}
$$

where $z_{y}$ and $z_{w}$ denote the income and wealth poverty thresholds. The U.S. counterfactual poverty incidence is then given by

$$
\begin{aligned}
P_{U S}^{C}\left(z_{Y}^{U S}, z_{W}^{U S}\right) & =F_{U S}^{C}\left(z_{Y}^{U S}, z_{W}^{U S}\right)= \\
& =E_{U S}\left[1\left(Y \leq z_{Y}^{U S}, W \leq z_{W}^{U S}\right) \frac{p_{S P}(J=j)}{p_{U S}(J=j)}\right]
\end{aligned}
$$

To measure the impact of the household structure on the poverty rate, we can decompose the difference in poverty rates between the U.S. and Spain in the following way

$$
\begin{aligned}
P_{U S}\left(z_{Y}^{U S}, z_{W}^{U S}\right)-P_{S P}\left(z_{Y}^{S P}, z_{W}^{S P}\right)= & {\left[P_{U S}\left(z_{Y}^{U S}, z_{W}^{U S}\right)-P_{U S}^{C}\left(z_{Y}^{U S}, z_{W}^{U S}\right)\right]+} \\
& +\left[P_{U S}^{C}\left(z_{Y}^{U S}, z_{W}^{U S}\right)-P_{S P}\left(z_{Y}^{S P}, z_{W}^{S P}\right)\right]
\end{aligned}
$$

${ }^{33}$ The results for the other groups of poor households can be easily derived by simply modifying the argument of the indicator function. 
where the terms in the first square brackets represent the share of the poverty gap explained by cross-national differences in household characteristics, while the terms in the second square brackets indicate the contribution due to differences in the conditional poverty function. Table 8 shows the results of the decomposition analysis. The first set of results corresponds to the classification of households used in Table 7, which differentiates 19 types of households according to the sex and age of the head and the type of living arrangement. Furthermore, in order to check the robustness of the results, we replicate the analysis using an alternative classification that defines 12 groups using these same variables. In addition, to assess the effect of each particular household type, Table 9 presents the difference between the U.S. actual and counterfactual poverty rates, when the later is computed considering only the variation in one household type at a time. Notice this is just a particular case of the decomposition method discussed above in which the set $J$ includes only two groups of households: the group of interest and the rest.

Differences in the household structure between Spain and the U.S. contribute to explain the differences in the incidence of poverty observed in these two countries. Interestingly, we find that poverty rates in the U.S. always reduce when the Spanish household structure is assumed. This effect is particularly striking for those groups whose incidence differs the most between the two countries, namely, the twice-poor and vulnerable-non poor groups. In fact, the incidence of these groups in the U.S. reduces by about one third (one quarter in the case of non-housing wealth) when the U.S. household structure is replaced by the Spanish one, whatever the classification of households considered. Thus, controlling for the age distribution and living arrangements accounts for a significant share of the poverty gap between Spain and the U.S. For the twice-poor group this factor accounts for about 45 or 58 percent of the gap depending on the wealth variable used. In the case of the vulnerable-non poor, household demographics explain more than 80 percent of the difference between countries in the case of housing wealth, whereas in the case of non-housing wealth switching the household structure leads to an increase in the poverty gap between Spain and the U.S. ${ }^{34}$

[Place Table 8 here]

\footnotetext{
${ }^{34}$ Notice that the incidence of this group when the housing equity is removed is larger in Spain than in the U.S.
} 
Regarding the effect by household types, we find important differences among the three poverty groups. In the case of the twice-poor, the larger share of single households under 35 in the U.S. is a key factor to understand the effect of the household structure. Indeed, it is the group of single women and lone-mother households which causes the largest change in the U.S. counterfactual poverty rate. Thus, in the case of income and net worth, the incidence of twice-poor in the U.S. reduces by about 10 percent when either the proportion of women under 25 living alone or the rate of single mothers between 25 and 35 in the U.S. is set equal to that in Spain. This result points out to crosscountry differences in the formation of this type of households. Although the female labor participation rate has steadily increased in Spain since the opening of the economy in the 60's, there still exists a substantial difference in participation rates between Spain and other rich countries, especially in the case of married mothers (Mumford and Parera 2001, Costa 2000). Moreover, despite the general increase in the number of lone-mothers due to divorce and teenage pregnancy observed in most developed countries (Reher, 1998), there exist important cross-country differences in the living arrangements of female headed households. Indeed, in Spain, about 30 percent of lone-mothers co-reside with their own family, while in the U.S. this percentage is about 15 percent (Reher 1998 and London 1998), which would contribute to explain the lower incidence of this households observed in Spain.

For the protected-poor group, differences in the incidence of non-single households at the end of the life-cycle have the largest impact on the counterfactual poverty estimates. Households headed by retired people are especially likely to be in a low-income and highwealth situation, as they count with the value of savings accumulated over the working life. Consequently, the large incidence of couple households above 65 years old in Spain relative to the U.S. (19 versus 11 percent, see Table 7) rises the number of protected-poor households in the U.S. by more than 12 percent. Lastly, single males under 25 and single females between 35 and 50 cause the greatest changes in the number of vulnerable-non poor. In fact, the low incidence of young people living alone in Spain significantly reduces the incidence of vulnerable-non poor in the U.S. For instance, in the case of income and net worth, switching the proportion of single males under 25 in the U.S. by that in Spain, would reduce the U.S. poverty rate more than 7 percent.

[Place Table 9 here] 


\section{Conclusions}

In this paper we have used two highly comparable surveys such as the SCF 2001 and the EFF 2002 to quantify and to characterize households that are poor in income and wealth in the U.S. and Spain. We complement the standard income-poverty approach in which poverty is identified with the lack of adequate income, using information on households' wealth holdings in order to identify those households that are more vulnerable in periods of economic crisis where households income falls. For doing so, we depart from the annuity approach that combines information on income and wealth into a single welfare index, and we specify a poverty line for each dimension, so that households that hold an insufficient level of either income or wealth are identified. Thus, this methodology, in contrast with the annuity method, allows us to characterize vulnerable-non poor households, that is, households whose incomes are above the poverty line but hold few assets, which makes them vulnerable if current income were to be reduced or disappeared entirely. Moreover, it also allows us to identify protected-poor, as well as, twice-poor households. The former refers to households with incomes below the income threshold but with sufficient wealth holdings to maintain a minimum standard of living, while the latter category includes all the households that are deprived in both dimensions.

We quantify and characterize these groups of poor households in the U.S. and in Spain, two countries whose social protection systems are usually catalogued as rather weak, which makes the consideration of wealth holdings in poverty measurement in these countries even more relevant, given the importance that private insurance mechanisms have for households in order to protect themselves against income shocks in a context with low social protection. Importantly, we find that the poverty profile based on income and wealth is quite different to that derived from income-poverty analysis. In fact, the characteristics of the poor differ importantly across the three groups of poor households defined in terms of income and wealth. Thus, the risk of belonging to one of these groups changes over the life-cycle. Among those situated above the income poverty line, it is households at early stages of the life cycle which are particularly more vulnerable to negative income shocks, as they are less likely to hold some assets that allow them to overcome low-income periods. Further, the probability that an income-poor household will have enough wealth holdings to smooth consumption increases with the age of head, so that, households with heads above 65 years of age are clearly over-represented in the protected-poor group. In contrast, among those that are income constrained, households headed by young individuals are more likely to be also wealth-poor, so that, the incidence of twice-poor households is greater among those under 35. 
Despite the similar poverty profile in the U.S. and Spain, the proportion of households that are either affected by income or wealth poverty is larger in the U.S. than in Spain. In particular, we find that the proportion of twice-poor and vulnerable-non poor is significantly larger among U.S. households, whereas the rate of protected-poor is quite similar in the two countries. We use multidimensional counterfactual distribution analysis to determine the extent to which the difference in the relative size of poor groups in the U.S. is explained by a larger vulnerability of U.S. households or by the distribution of poverty-relevant characteristics. Our results indicate that differences in the household structure in Spain and the U.S. account for a significant share of the poverty gap in the case of twice-poor and vulnerable-non poor households, which suggests that the household formation process is a factor that must be taken into account when performing cross-national comparisons on income and asset-poverty. However, there is a significant share of the poverty gap that cannot be explained by this factor and, therefore, other elements must be brought into consideration to explain this feature. In particular, a relevant one might be linked to the differences in the degree of generosity of the Social Protection System which will imply differences in incentives for households in order to work and save for unprotected risks. For instance, as a recent comparison of social security systems across OECD countries by Alonso (2009) suggests, the gross replacement rate of social security benefits, measured as the ratio of those benefits to average net earnings, is more than twice larger in Spain than in the U.S. Furthermore, these two countries also differ regarding the extent of coverage of their unemployment insurance systems. Thus, while in Spain the average replacement rate is above 67 percent and the benefit duration is 21 months, in the U.S. these figures are about 54 percent and 6 months (OECD, 2006). However, the net effect of these differences in public programs on the income and wealth poverty gap is not a priori clear: while they help to reduce income-poverty by providing liquidity during low-income periods, they could induce households to save less affecting the incidence of asset-poor households. The contribution that this and other factors, such as the differences in attitude toward risk, or income volatility, make in explaining the poverty gap is left for further research. 


\section{Appendix}

\subsection{Information in the EFF and the SCF}

[Place Table A.1 here]

(1) This category includes gold, silver, works of art, jewelry, antiques, stamps collections, and other miscellaneous assets in the household.

\subsection{Education Coding}

To group households according the educational level of the head we follow the International Standard Classification of Education (ISCED) provided by the UNESCO:

- LOW includes no education, pre-primary, primary, lower secondary, compulsory and initial vocational education.

- MEDIUM includes upper secondary general education, basic vocational education, and post-secondary education.

- HIGH includes specialized vocational education, university/college education and (post)-doctorate and equivalent degrees.

\subsection{Income and Non-Housing Wealth Poverty}

[Place Table A.2 here]

[Place Table A.3 here]

\subsection{Household Structure in Spain and the U.S.}

The distribution of poverty-relevant characteristics is a factor that contributes to explain differences in the incidence of poverty across countries (Biewen and Jenkins, 2005). Thus, a poverty gap may be explained simply because of a larger presence of more vulnerable groups. Table A.4 shows the distribution by socioeconomic characteristics of U.S. and Spanish households. As the figures in the table show, despite the large number of working household heads in the U.S., the distribution of households regarding the labour status 
is very similar in the two countries. This result is also obtained when we look at the presence of children: in both countries around 70 percent of households lack of children. As noted already in the text, the main differences between the two populations are observed regarding the age distribution and the type of living arrangement. In particular, young households under 35 have a large presence in the U.S. population. Also, the number of single households in the U.S. is more than twice that of Spain (30 versus 15 percent), whereas the presence of households with three or four members in Spain is about twice that in the United Kingdom (24 versus 12 and 14 percent, respectively). Moreover, the larger presence of single households among U.S. households is related to the civil status of the head. Indeed, the proportion of households whose head is divorced or has never married is larger among U.S. households which clearly contributes to explain the larger presence of single households observed in this country. Finally, information on education reveals a significant difference between Spain and the U.S. In fact, the proportion of households headed by a person with low educational attainment is significantly larger in Spain than in the U.S. (59 and 12 percent), whereas the proportion of households with a highly educated head in the U.S. is twice that in Spain. However, results available upon request, show that the main conclusions on the role of the household structure to explain differences in the incidence of multidimensional poor groups still hold when we control for differences in education.

[Place Table A.4 here] 


\section{References}

[1] Alonso, J. (2009). "Social Security and Retirement across the OECD countries". Working Paper, Arizona State University.

[2] Azpitarte, F. (2011). "Measurement and Identification of Asset-Poor Households: a Cross-National Comparison between Spain and the United Kingdom", Journal of Economic Inequality, Vol. 9, No. 1, pp. 87-110.

[3] Biewen, M., and Jenkins, S. P. (2005). "Accounting for Poverty Differences between the United States, Great Britain and Germany". Empirical Economics, Vol. 30, Ed. 2. pp. 331-358.

[4] Bover, O. (2004). "The Spanish Survey of Household Finances (EFF): Description and Methods of the 2002 Wave". Occasional paper No.0409, Banco de España.

[5] Bover, O. (2010). "Wealth Inequality and Household Structure: US vs. Spain". Review of Income and Wealth, Vol. 56, No. 2, pp. 259-290.

[6] Bover, O, Martínez-Carrascal, C., and Velilla, P. (2005). "The Wealth of Spanish Households: a Microcomparison with the United States, Italy and the United Kingdom". Economic Bulletin of the Bank of Spain 07/2005.

[7] Brandolini, A., Silvia, M., and Smeeding, T. M. (2010). "Asset-based measurement of poverty". Journal of Policy Analysis and Management, Vol. 29, No. 2, pp. 267-284.

[8] Budria, S., Díaz-Jiménez, J., Quadrini, V., and Ríos-Rull, J. V. (2002). "Updated Facts on the U.S. Distributions of Earnings, Income and Wealth". Federal Reserve Bank of Minneapolis Quarterly Review Summer, Vol. 26, No. 3, pp. 2-35.

[9] Buhmann, B., Rainwater, L., Schmauss, G., Smeeding, T. (1988). "Equivalence Scales, Well-Being, Inequality, and Poverty: Sensitivity Estimates across Ten Countries Using the Luxembourg Income Study (LIS) Database". Review of Income and Wealth, Vol. 34, No. 2, pp. 115-42.

[10] Cameron, A. C. and Trivedi, P. K. (2005). Microeconometrics: Methods and Applications. Cambridge University Press, New York, May 2005.

[11] Caner, A., and Wolff, E. N. (2004). "Asset Poverty in the United States, 1984-1999: Evidence from the Panel Study of Income Dinamics". Review of Income and Wealth, Series 50, Vol. 4, pp. 493-518. 
[12] Christensen, A.-K., Dupont J., and Schreyer P. (2005). "International Comparability of the Consumer Price Index: Owner-Occupied Housing". Paper prepared for the OECD Seminar, Inflation Measures: Too High-Too Low-Internationally Comparable? Paris, June 21-22.

[13] Costa, Dora L., (2000). "From Mill Town to Board Room: the Rise of Women's Paid Labor". Journal of Economic Perspectives, Vol. 14, No. 4, pp. 101-122.

[14] Davies, J. B. and Shorrocks A. F. (2000). "The Distribution of Wealth", in A. B. Atkinson and F. Bourguignon (eds.) Handbook of Income Distribution, Vol. 1, pp. 605-75. Amsterdam: North-Holland.

[15] Esping-Andersen, G., Gallie, D., Hemerijck, A., and Myles, J. (2002). Why We Need a New Welfare State. Oxford, UK: Oxford University Press.

[16] Heady, B. and Wooden, M. (2004). "The Effects of Wealth and Income on Subjective Well-being and Ill-being". The Economic Record, Vol. 80, Special Issue, pp. S24-S33.

[17] Heady, B. and Wooden, M. (2005). "The importance of wealth for subjective wellbeing". Journal of Financial Transformation, Vol. 15, pp. 59-67.

[18] Hubbard, R. G., Skinner, J., and Zeldes, P. (1995). "Precautionary Saving and Social Insurance". The Journal of Political Economy, Vol. 103, No. 2, pp. 360-399.

[19] Jäntti, M. and Danziger, S. (2000). "Income poverty in advanced countries", in A.B. Atkinson \& F. Bourguignon (eds.) Handbook of Income Distribution, Vol 1, pp. 309-378. Amsterdam: North-Holland.

[20] Jäntti, M., Sierminska, E., and Smeeding, T. (2008). "The Joint Distribution of Household Income and Wealth: Evidence from the Luxembourg Wealth Study". OECD Social Employment and Migration Working Papers, No. 65, OECD Publishing.

[21] Jarvis, S. and Jenkins, S. P. (1998). "Low Income Dynamics in 1990s Britain". Fiscal Studies, Vol. 18, No. 2, pp. 123-142.

[22] Jesuit, D. and Smeeding T. (2002). "Poverty and Income Distribution". Working Paper No. 293, Luxembourg Income Study.

[23] Kennickell, A. (1998). Multiple Imputation in the Survey of Consumer Finances. 
[24] Kennickell, A. (2000). Wealth Measurement in the Survey of Consumer Finances: Methodology and Directions for Future Research.

[25] Kennickell, A. (2008). "The Role of Over-Sampling of the Wealthy in the Survey of Consumer Finances". Irving Fisher Committee Bulletin No. 28, August, 2008.

[26] London, R. A. (1998). "Trends in single mothers' living arrangements from 1970 to 1995: correcting the Current Population Survey". Demography, Vol. 3, No.1, pp. $125-131$.

[27] Mumford, K. and Parera, A. (2001). "The Labor Force Participation of Married Mothers in Spain and Britain". Discussion Papers in Economics, University of York, No.2001/10.

[28] Notten, G. and Neubourg de, C. (2007). "Relative or absolute poverty in the US and EU? The battle of the rates". MGSoG Working Paper, 2007/001, Maastricht Graduate School of Governance, Maastricht University, Maastricht.

[29] OECD. (2006). Unemployment Outlook 2006. Boosting Jobs and Incomes. ISBN 92-64-02384-4

[30] OECD (2008). Growing Unequal? Income Distribution and Poverty in OECD Countries, Paris: OECD.

[31] Radner, D. and Vaughan, D. (1987). "Wealth, Income, and the Economic Status of Aged Households" in E. Wolff (eds.), International Comparisons of the Distribution of Household Wealth.

[32] Reher, D. S. (1998). "Family ties in Western Europe: persistent contrasts". Population and Development Review, Vol. 24, No. 2, pp. 203-234.

[33] Short, K. and Ruggles, P. (2006). "Experimental Measures of Poverty and Net Worth: 1996". Journal of Income Distribution, Special issue on assets and poverty, pp. 8-21.

[34] Shorrocks, A. F., (1978). "The Measurement of Mobility". Econometrica, Vol. 46, pp. 1013-1024.

[35] Sierminska, E. and Smeeding T. M. (2005). "Measurement Issues: Equivalence Scales, Accounting Framework, and Reference Unit". Paper presented at the Luxembourg Wealth Study Workshop, Perugia, 27-29 January 2005. 
[36] Silber, J. (2007). "Measuring poverty: taking a multidimensional perspective". Hacienda Pública Española, IEF, Vol. 182, No. 3, pp. 29-74.

[37] Smeeding, T. (2006). "Poor People in Rich Nations: The United States in Comparative Perspective". Journal of Economic Perspectives, Vol. 20, No. 1 (Winter), pp. 69-90.

[38] Van den Bosch, K. (1998). "Poverty and Assets in Belgium". Review of Income and Wealth, Vol. 44, No. 2, pages 215-228.

[39] Weisbrod, B. and Hansen W.L. (1968). "An Income-Net Worth Approach to Measuring Economic Welfare”. American Economic Review, Vol. 58, pp. 1315-1329.

[40] Wolff, E. N. (1990). "Wealth holdings and Poverty Status in the U.S." Review of Income and Wealth, Vol. 30, No. 2, pp. 143-165.

[41] Zagorsky, J. L.(2006). "Measuring Poverty Using both Income and Wealth". Journal of Income Distribution, Special issue on assets and poverty, pp. 22-40. 
Table 1

Income sources in Spain and the U.S.

(all variables in percentage)

\begin{tabular}{|c|c|c|c|c|}
\hline \multirow[b]{2}{*}{ Number of active earners ${ }^{(1)}$} & \multicolumn{2}{|c|}{ Spain } & \multicolumn{2}{|c|}{ U.S. } \\
\hline & \multicolumn{2}{|c|}{$\%$ households } & \multicolumn{2}{|c|}{$\%$ households } \\
\hline 0 & \multicolumn{2}{|c|}{28.8} & \multicolumn{2}{|c|}{19.4} \\
\hline 1 & \multicolumn{2}{|c|}{38.4} & \multicolumn{2}{|c|}{48.3} \\
\hline \multirow[t]{2}{*}{2 or more } & \multicolumn{2}{|c|}{32.8} & \multicolumn{2}{|c|}{32.3} \\
\hline & \multicolumn{2}{|c|}{100} & \multicolumn{2}{|c|}{100} \\
\hline Income sources & $\begin{array}{c}\% \text { households } \\
\text { perceiving }\end{array}$ & $\begin{array}{c}\% \text { of total } \\
\text { income }\end{array}$ & $\begin{array}{c}\% \text { households } \\
\text { perceiving }\end{array}$ & $\begin{array}{c}\% \text { of total } \\
\text { income }\end{array}$ \\
\hline Wage and salaries & 66.0 & 62.3 & 77.3 & 74.4 \\
\hline Self-employment & 16.5 & 14.7 & 8.0 & 9.7 \\
\hline Property income & 25.3 & 3.5 & 35.6 & 6.2 \\
\hline Occupational pensions and transfers (2) & 48.6 & 19.0 & 39.9 & 9.6 \\
\hline Other income & 1.3 & 0.5 & 0.9 & 0.1 \\
\hline & & 100 & & 100 \\
\hline
\end{tabular}

Source: Author's calculations using EFF 2002 and data from the SCF 2001 included in the LWS database.

(1) Every household member who received income from wages, salaries or self-employment activities is considered an active earner.

(2) Transfers include social security pensions, social insurance transfers, and other private transfers. 
Table 2

The wealth portfolio composition in Spain and the U.S.

(all variables in percentage)

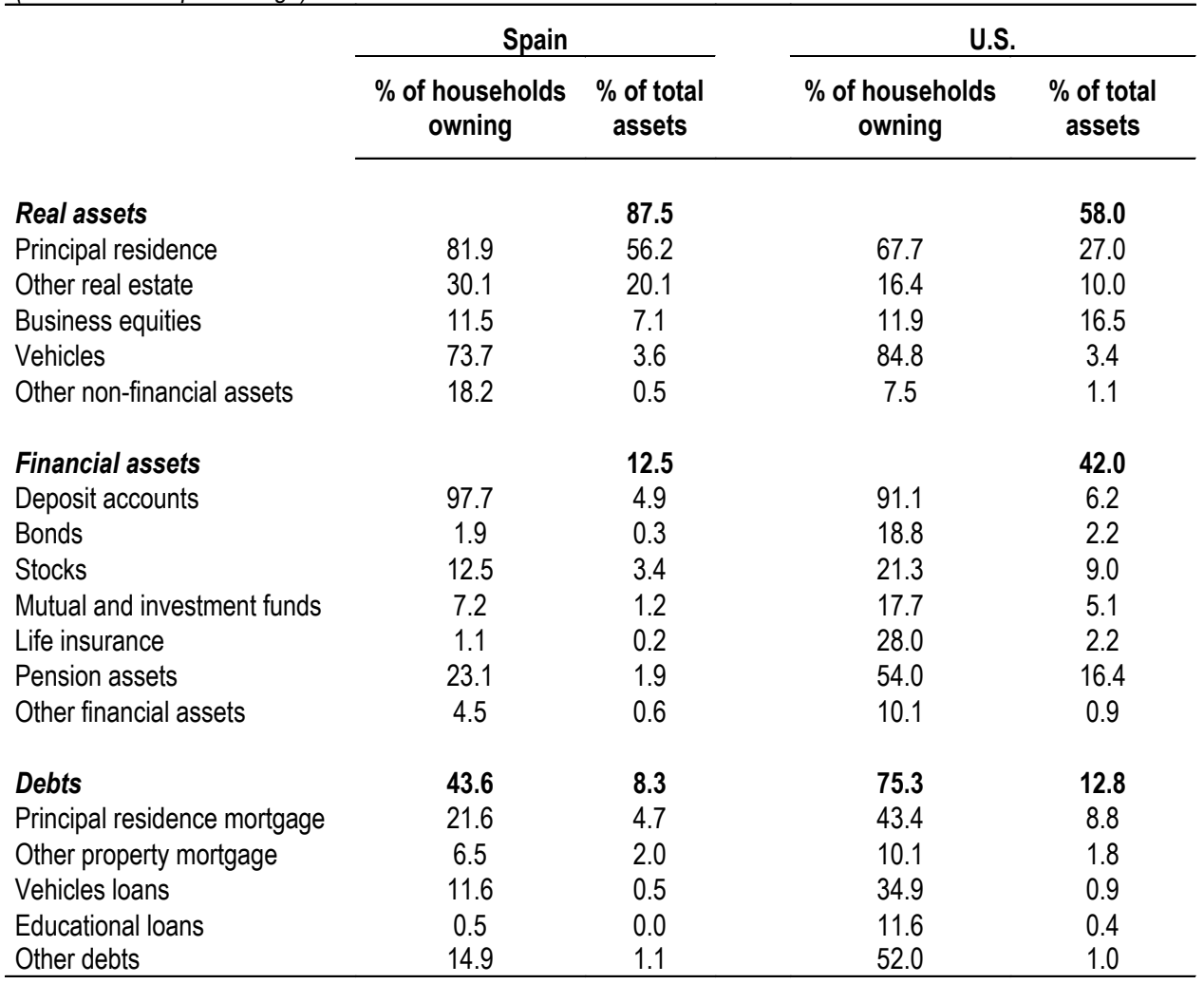

Source: Author's calculations using EFF 2002 and data from the SCF 2001 included in the LWS database. 
Table 3

Correlation and re-ranking in the distribution of income and wealth in Spain and the U.S. (1)

Correlation coefficient between income and wealth (2)

\begin{tabular}{lccccc} 
& \multicolumn{3}{c}{ Correlation coefficient between income and wealth (2) } \\
\cline { 2 - 3 } & $\begin{array}{c}\text { Spain } \\
\text { All }\end{array}$ & & \multicolumn{3}{c}{ U.S. } \\
\cline { 2 - 3 } \cline { 5 - 6 } & 0.18 & & 0.50 & 0.52 & 0.48 \\
Income - Net worth & 0.15 & & 0.48 & 0.52 & 0.46 \\
Income - Non-housing & 0.32 & & 0.36 & 0.35 & 0.40 \\
$\ldots .$. \\
Income - Housing wealth & 0.99 & & 0.99 & 0.99 & 0.99 \\
Net worth - Non-housing & 0.20 & & 0.51 & 0.52 & 0.46 \\
Net worth - Housing wealth & 0.11 & & 0.44 & 0.46 & 0.37
\end{tabular}

Re-ranking in the quartile distribution of income and wealth

\section{Spain}

\begin{tabular}{|c|c|c|c|c|}
\hline \multicolumn{5}{|c|}{ Net worth } \\
\hline Income & 1 & 2 & 3 & 4 \\
\hline 1 & 39 & 29 & 21 & 12 \\
\hline 2 & 29 & 29 & 25 & 18 \\
\hline 3 & 21 & 26 & 28 & 24 \\
\hline 4 & 11 & 16 & 26 & 47 \\
\hline
\end{tabular}

U.S.

\begin{tabular}{ccccc}
\hline \multicolumn{3}{c}{ Net worth } \\
Income & $\mathbf{1}$ & $\mathbf{2}$ & $\mathbf{3}$ & $\mathbf{4}$ \\
$\mathbf{1}$ & 52 & 24 & 17 & 7 \\
$\mathbf{2}$ & 30 & 32 & 23 & 15 \\
$\mathbf{3}$ & 13 & 33 & 30 & 23 \\
$\mathbf{4}$ & 4 & 11 & 29 & 55
\end{tabular}

Mobility index $M(P)=0.83$

\begin{tabular}{lcc}
\multicolumn{2}{c}{$\begin{array}{c}\text { Mean values of the income-poor expressed as percentage of } \\
\text { those of the non-income poor (4) }\end{array}$} \\
\cline { 2 - 2 } & Spain & U.S. \\
\cline { 2 - 2 } $\begin{array}{l}\text { Income } \\
\text { Net worth }\end{array}$ & 25.7 & 12.8 \\
Non-housing wealth & 46.3 & 16.9 \\
Housing wealth & 26.5 & 13.0 \\
& 62.0 & 31.9
\end{tabular}

Source: Author's calculations using EFF 2002 and data from the SCF 2001 included in the LWS database.

(1) Income and wealth variables are adjusted using the square root equivalence scale according to which each variable is divided by the square root of the household size.

(2) In the case of Spain the information about the ethnicity of the head is not reported in the EFF.

(3) The diagonal index $M(P)$ is equal to $((n-\operatorname{tr}(P)) /(n-1)$, where $n$ is the number of percentiles and $\operatorname{tr}(P)$ is the trace of the transition matrix. Notice that when there is no mobility the index is equal to zero, while in the case of maximal mobility it is equal to $(n /(n-1))$.

(4) Income-poor households are defined as those whose gross income is less or equal than 50 percent of the median equivalent household income. 
Table 4

Income-wealth poverty rates in Spain and the U.S.

(all variables in percentage)

Poverty headcount ratio

$\left(\mathbf{Z}_{\mathbf{w}}=\right.$ wealth-poverty line expressed as a proportion of the income-poverty line $\left.\mathbf{Z}_{\mathbf{y}}{ }^{(1)}\right)$

\begin{tabular}{|c|c|c|c|c|c|c|c|c|c|}
\hline \multicolumn{5}{|c|}{ Spain } & \multicolumn{5}{|c|}{ U.S. } \\
\hline $\begin{array}{l}\text { Income - } \\
\text { poor }\end{array}$ & $\begin{array}{l}\text { Twice- } \\
\text { poor }\end{array}$ & $\begin{array}{c}\text { Protected } \\
\text { poor }\end{array}$ & $\begin{array}{c}\text { Vulnerable } \\
\text { non-poor }\end{array}$ & $\begin{array}{l}\text { Non- } \\
\text { poor }\end{array}$ & $\begin{array}{c}\text { Income - } \\
\text { poor }\end{array}$ & $\begin{array}{l}\text { Twice- } \\
\text { poor }\end{array}$ & $\begin{array}{c}\text { Protected } \\
\text { poor }\end{array}$ & $\begin{array}{c}\text { Vulnerable } \\
\text { non-poor }\end{array}$ & $\begin{array}{l}\text { Non- } \\
\text { poor }\end{array}$ \\
\hline
\end{tabular}

Income \& Net worth (2)

\begin{tabular}{|c|c|c|c|c|c|c|c|c|c|c|}
\hline \multicolumn{11}{|l|}{$Z_{y}=60 \%$} \\
\hline$Z_{w}=Z_{y} / 12$ & 23.6 & 2.5 & 21.1 & 2.3 & 74.1 & 29.2 & 9.2 & 20.1 & 4.5 & 66.3 \\
\hline$Z_{W}=Z_{y} / 4$ & 23.6 & 3.9 & 19.7 & 3.8 & 72.6 & 29.2 & 11.7 & 17.6 & 6.9 & 63.8 \\
\hline$Z_{W}=Z_{y} / 2$ & 23.6 & 4.7 & 18.9 & 5.4 & 71.0 & 29.2 & 14.0 & 15.3 & 9.7 & 61.0 \\
\hline \multicolumn{11}{|l|}{$Z_{y}=50 \%$} \\
\hline$Z_{w}=Z_{y} / 12$ & 15.7 & 1.6 & 14.1 & 2.6 & 81.7 & 23.3 & 7.6 & 15.7 & 5.5 & 71.2 \\
\hline$Z_{W}=Z_{y} / 4$ & 15.7 & 2.5 & 13.2 & 4.7 & 79.6 & 23.3 & 9.9 & 13.4 & 7.7 & 69.0 \\
\hline$Z_{w}=Z_{y} / 2$ & 15.7 & 3.1 & 12.6 & 6.2 & 78.1 & 23.3 & 11.5 & 11.8 & 10.9 & 65.8 \\
\hline \multicolumn{11}{|l|}{$Z_{y}=40 \%$} \\
\hline$Z_{W}=Z_{y} / 12$ & 8.8 & 0.9 & 7.9 & 2.9 & 88.3 & 17.5 & 6.1 & 11.4 & 6.4 & 76.1 \\
\hline$Z_{w}=Z_{y} / 4$ & 8.8 & 1.2 & 7.6 & 5.5 & 85.7 & 17.5 & 7.8 & 9.7 & 8.8 & 73.8 \\
\hline$Z_{w}=Z_{y} / 2$ & 8.8 & 1.5 & 7.3 & 7.1 & 84.1 & 17.5 & 8.9 & 8.6 & 11.5 & 71.0 \\
\hline
\end{tabular}

Income \&

Non-housing wealth

\begin{tabular}{|c|c|c|c|c|c|c|c|c|c|c|}
\hline \multicolumn{11}{|l|}{$Z_{y}=60 \%$} \\
\hline$Z_{w}=Z_{y} / 12$ & 23.6 & 6.5 & 17.1 & 8.0 & 68.4 & 29.2 & 10.9 & 18.3 & 6.5 & 64.3 \\
\hline$Z_{W}=Z_{y} / 4$ & 23.6 & 10.3 & 13.3 & 13.8 & 62.6 & 29.2 & 15.1 & 14.1 & 10.0 & 60.8 \\
\hline$Z_{w}=Z_{y} / 2$ & 23.6 & 13.7 & 9.9 & 21.6 & 54.8 & 29.2 & 18.9 & 10.4 & 14.4 & 56.4 \\
\hline \multicolumn{11}{|l|}{$Z_{y}=50 \%$} \\
\hline$Z_{w}=Z_{y} / 12$ & 15.7 & 4.1 & 11.6 & 8.9 & 75.4 & 23.3 & 9.2 & 14.1 & 7.5 & 69.2 \\
\hline$Z_{W}=Z_{y} / 4$ & 15.7 & 6.8 & 8.9 & 15.3 & 68.9 & 23.3 & 12.5 & 10.8 & 10.7 & 66.0 \\
\hline$Z_{W}=Z_{y} / 2$ & 15.7 & 9.1 & 6.7 & 23.2 & 61.1 & 23.3 & 15.3 & 8.0 & 15.7 & 61.0 \\
\hline \multicolumn{11}{|l|}{$Z_{y}=40 \%$} \\
\hline$Z_{w}=Z_{y} / 12$ & 8.8 & 2.3 & 6.5 & 9.4 & 81.8 & 17.5 & 7.2 & 10.2 & 8.6 & 74.0 \\
\hline$Z_{W}=Z_{y} / 4$ & 8.8 & 3.6 & 5.2 & 16.6 & 74.6 & 17.5 & 9.7 & 7.8 & 11.9 & 70.7 \\
\hline$Z_{w}=Z_{y} / 2$ & 8.8 & 4.8 & 4.1 & 23.4 & 67.8 & & 11.5 & 6.0 & 16.8 & 65.7 \\
\hline
\end{tabular}

Source: Author's calculations using EFF 2002 and data from the SCF 2001 included in the LWS database.

(1) The income poverty line, $\mathbf{Z}_{\mathbf{y}}$, is defined as $\%$ of the median equivalent household income.

(2) The components included in the net worth measure are described in Section 2. Non-housing wealth is equal to net worth minus the net value of the principal residence. In both cases, the values are equivalised dividing by the square root of the household size. 


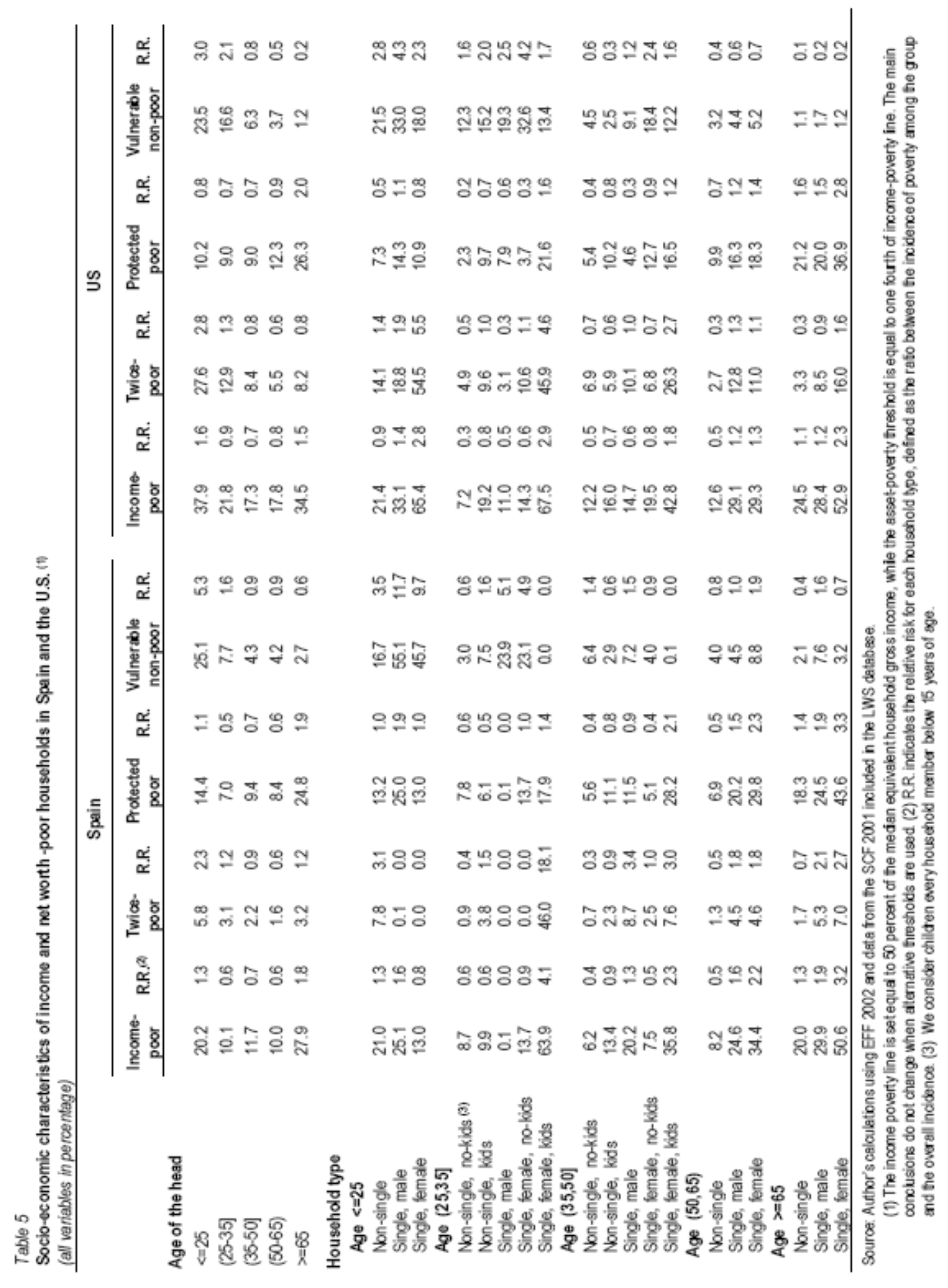


Table 6

Regression on the probability of income and net worth-poverty in Spain and the U.S. (1) (standard errors in parenthesis)

\begin{tabular}{|c|c|c|c|c|c|c|c|c|}
\hline & \multicolumn{4}{|c|}{ Spain } & \multicolumn{4}{|c|}{ US } \\
\hline & $\begin{array}{l}\text { Income } \\
\text {-poor }\end{array}$ & $\begin{array}{l}\text { Twice- } \\
\text { poor }\end{array}$ & $\begin{array}{l}\text { Protected } \\
\text { poor }\end{array}$ & $\begin{array}{l}\text { Vulnerable } \\
\text { non-poor }\end{array}$ & $\begin{array}{l}\text { Income- } \\
\text { poor }\end{array}$ & $\begin{array}{l}\text { Twice- } \\
\text { poor }\end{array}$ & $\begin{array}{l}\text { Protected } \\
\text { poor }\end{array}$ & $\begin{array}{c}\text { Vulnerable } \\
\text { non-poor }\end{array}$ \\
\hline Constant & $\begin{array}{l}-2.1^{* *} \\
(0.5)\end{array}$ & $\begin{array}{c}-3.8^{* *} \\
(0.6)\end{array}$ & $\begin{array}{c}-1.6^{* *} \\
(0.4)\end{array}$ & $\begin{array}{c}-1.8^{* *} \\
(0.5)\end{array}$ & $\begin{array}{l}-3.8^{* *} \\
(0.4)\end{array}$ & $\begin{array}{l}-3.9^{* *} \\
(0.4)\end{array}$ & $\begin{array}{l}-2.6^{* *} \\
(0.4)\end{array}$ & $\begin{array}{c}-1.7^{* *} \\
(0.4)\end{array}$ \\
\hline $\begin{array}{l}\text { Age, sex, and race } \\
\text { of the head }\end{array}$ & & & & & & & & \\
\hline$<=25$ & $\begin{array}{l}0.9 * \\
(0.5)\end{array}$ & $\begin{array}{l}1.7^{* *} \\
(0.5)\end{array}$ & $\begin{array}{l}0.9^{* *} \\
(0.4)\end{array}$ & $\begin{array}{l}1.4^{* *} \\
(0.3)\end{array}$ & $\begin{array}{l}1.3^{* *} \\
(0.2)\end{array}$ & $\begin{array}{l}1.7^{* *} \\
(0.2)\end{array}$ & $\begin{array}{l}1.0^{* *} \\
(0.2)\end{array}$ & $\begin{array}{l}1.4^{* *} \\
(0.2)\end{array}$ \\
\hline$(25-35]$ & $\begin{array}{c}0.2 \\
(0.2)\end{array}$ & $\begin{array}{l}1.0^{* *} \\
(0.2)\end{array}$ & $\begin{array}{l}-0.04 \\
(0.2)\end{array}$ & $\begin{array}{c}0.2 \\
(0.2)\end{array}$ & $\begin{array}{l}0.2^{*} \\
(0.1)\end{array}$ & $\begin{array}{l}0.5^{* *} \\
(0.1)\end{array}$ & $\begin{array}{l}0.2^{*} \\
(0.1)\end{array}$ & $\begin{array}{l}0.9 * * \\
(0.1)\end{array}$ \\
\hline$(50-65]$ & $\begin{array}{l}-0.2 \\
(0.2)\end{array}$ & $\begin{array}{l}-0.3 \\
(0.3)\end{array}$ & $\begin{array}{l}-0.1 \\
(0.2)\end{array}$ & $\begin{array}{l}-0.2 \\
(0.2)\end{array}$ & $\begin{array}{l}0.04 \\
(0.2)\end{array}$ & $\begin{array}{l}-0.4^{\text {** }} \\
(0.2)\end{array}$ & $\begin{array}{c}0.2 \\
(0.1)\end{array}$ & $\begin{array}{l}-0.4^{* *} \\
(0.2)\end{array}$ \\
\hline$(65-75]$ & $\begin{array}{c}0.2 \\
(0.2)\end{array}$ & $\begin{array}{l}-0.2 \\
(0.3)\end{array}$ & $\begin{array}{c}0.3 \\
(0.2)\end{array}$ & $\begin{array}{l}-0.5^{*} \\
(0.3)\end{array}$ & $\begin{array}{l}0.3 \\
(0.3)\end{array}$ & $\begin{array}{l}-0.4^{*} \\
(0.3)\end{array}$ & $\begin{array}{l}0.3 \\
(0.2)\end{array}$ & $\begin{array}{c}-1.0^{* *} \\
(0.3)\end{array}$ \\
\hline$>75$ & $\begin{array}{l}0.5^{*} \\
(0.3)\end{array}$ & $\begin{array}{l}-0.2 \\
(0.4)\end{array}$ & $\begin{array}{l}0.5^{\text {** }} \\
(0.2)\end{array}$ & $\begin{array}{l}-0.5^{*} \\
(0.3)\end{array}$ & $\begin{array}{l}-0.1 \\
(0.3)\end{array}$ & $\begin{array}{c}-0.6^{* *} \\
(0.3)\end{array}$ & $\begin{array}{c}0.1 \\
(0.2)\end{array}$ & $\begin{array}{l}-0.9^{* *} \\
(0.3)\end{array}$ \\
\hline Female & $\begin{array}{c}-0.5^{* *} \\
(0.1)\end{array}$ & $\begin{array}{l}-0.3 \\
(0.2)\end{array}$ & $\begin{array}{l}-0.3^{* *} \\
(0.1)\end{array}$ & $\begin{array}{l}0.1 \\
(0.1)\end{array}$ & $\begin{array}{l}-0.01 \\
(0.1)\end{array}$ & $\begin{array}{l}-0.1 \\
(0.1)\end{array}$ & $\begin{array}{c}0.1 \\
(0.1)\end{array}$ & $\begin{array}{c}0.1 \\
(0.1)\end{array}$ \\
\hline Non white (2) & & & & & $\begin{array}{l}0.7^{* *} \\
(0.1)\end{array}$ & $\begin{array}{l}0.9^{* *} \\
(0.1)\end{array}$ & $\begin{array}{l}0.2^{* *} \\
(0.1)\end{array}$ & $\begin{array}{c}0.4^{* *} \\
(0.1)\end{array}$ \\
\hline Household type & & & & & & & & \\
\hline Size & $\begin{array}{c}-0.8^{* *} \\
(0.2)\end{array}$ & $\begin{array}{l}-0.3 \\
(0.3)\end{array}$ & $\begin{array}{c}-0.6^{* *} \\
(0.2)\end{array}$ & $\begin{array}{c}-0.5^{\text {** }} \\
(0.2)\end{array}$ & $\begin{array}{c}0.2 \\
(0.2)\end{array}$ & $\begin{array}{c}0.2 \\
(0.2)\end{array}$ & $\begin{array}{l}-0.1 \\
(0.2)\end{array}$ & $\begin{array}{l}-0.4 \\
(0.2)\end{array}$ \\
\hline Size ${ }^{\wedge} 2$ & $\begin{array}{l}0.1^{* *} \\
(0.0)\end{array}$ & $\begin{array}{c}0.1^{*} \\
(0.03)\end{array}$ & $\begin{array}{l}0.1^{* *} \\
(0.02)\end{array}$ & $\begin{array}{l}0.1^{* *} \\
(0.02)\end{array}$ & $\begin{array}{c}0.02 \\
(0.03)\end{array}$ & $\begin{array}{l}0.003 \\
(0.02)\end{array}$ & $\begin{array}{l}0.03^{*} \\
(0.02)\end{array}$ & $\begin{array}{l}0.04^{*} \\
(0.02)\end{array}$ \\
\hline Single & $\begin{array}{l}0.2 \\
(0.3)\end{array}$ & $\begin{array}{l}0.9^{* *} \\
(0.4)\end{array}$ & $\begin{array}{c}0.2 \\
(0.2)\end{array}$ & $\begin{array}{l}0.5^{*} \\
(0.3)\end{array}$ & $\begin{array}{l}1.4^{* *} \\
(0.2)\end{array}$ & $\begin{array}{l}1.5^{* *} \\
(0.2)\end{array}$ & $\begin{array}{l}0.7^{\text {** }} \\
(0.2)\end{array}$ & $\begin{array}{l}0.5^{\text {** }} \\
(0.2)\end{array}$ \\
\hline Lone parent & $\begin{array}{c}2.6^{* *} \\
(0.4)\end{array}$ & $\begin{array}{c}2.2^{* *} \\
(0.4)\end{array}$ & $\begin{array}{l}1.8^{* *} \\
(0.3)\end{array}$ & $\begin{array}{c}0.3 \\
(0.6)\end{array}$ & $\begin{array}{c}2.0^{* *} \\
(0.2)\end{array}$ & $\begin{array}{l}2.1^{\star *} \\
(0.2)\end{array}$ & $\begin{array}{l}1.4^{* *} \\
(0.2)\end{array}$ & $\begin{array}{l}1.1^{* *} \\
(0.2)\end{array}$ \\
\hline Couple with children (3) & $\begin{array}{l}1.0^{* *} \\
(0.2)\end{array}$ & $\begin{array}{l}0.5^{*} \\
(0.3)\end{array}$ & $\begin{array}{l}0.8^{* *} \\
(0.2)\end{array}$ & $\begin{array}{c}0.2 \\
(0.2)\end{array}$ & $\begin{array}{c}0.1 \\
(0.2)\end{array}$ & $\begin{array}{l}0.05 \\
(0.2)\end{array}$ & $\begin{array}{c}0.3 \\
(0.2)\end{array}$ & $\begin{array}{c}0.2 \\
(0.2)\end{array}$ \\
\hline $\begin{array}{l}\text { Education and } \\
\text { Labour status }{ }^{(4)}\end{array}$ & & & & & & & & \\
\hline Low educated head & $\begin{array}{l}1.0^{* *} \\
(0.2)\end{array}$ & $\begin{array}{l}0.6^{* *} \\
(0.2)\end{array}$ & $\begin{array}{c}0.7^{* *} \\
(0.1)\end{array}$ & $\begin{array}{l}0.4^{* *} \\
(0.1)\end{array}$ & $\begin{array}{l}1.3^{* *} \\
(0.1)\end{array}$ & $\begin{array}{l}1.3^{* *} \\
(0.1)\end{array}$ & $\begin{array}{l}0.8 \text { ** } \\
(0.1)\end{array}$ & $\begin{array}{l}0.4^{* *} \\
(0.2)\end{array}$ \\
\hline High educated head & $\begin{array}{l}-0.7^{*} \\
(0.3)\end{array}$ & $\begin{array}{l}-0.3 \\
(0.4)\end{array}$ & $\begin{array}{c}-0.6^{* *} \\
(0.2)\end{array}$ & $\begin{array}{c}-0.7^{\text {** }} \\
(0.3)\end{array}$ & $\begin{array}{c}-1.1^{* *} \\
(0.2)\end{array}$ & $\begin{array}{c}-0.8^{\text {** }} \\
(0.2)\end{array}$ & $\begin{array}{c}-0.8^{\text {** }} \\
(0.1)\end{array}$ & $\begin{array}{c}-0.5^{* *} \\
(0.1)\end{array}$ \\
\hline Unemployed & $\begin{array}{l}1.9^{* *} \\
(0.2)\end{array}$ & $\begin{array}{l}1.5^{\text {** }} \\
(0.3)\end{array}$ & $\begin{array}{l}1.5^{* *} \\
(0.2)\end{array}$ & $\begin{array}{l}1.0^{* *} \\
(0.2)\end{array}$ & $\begin{array}{l}1.2^{* *} \\
(0.2)\end{array}$ & $\begin{array}{l}1.2^{* *} \\
(0.2)\end{array}$ & $\begin{array}{l}0.8^{* *} \\
(0.2)\end{array}$ & $\begin{array}{l}0.5^{\text {** }} \\
(0.2)\end{array}$ \\
\hline Retired & $\begin{array}{l}0.9^{* *} \\
(0.2)\end{array}$ & $\begin{array}{l}1.0^{* *} \\
(0.3)\end{array}$ & $\begin{array}{l}0.5^{\text {** }} \\
(0.2)\end{array}$ & $\begin{array}{c}0.1 \\
(0.2)\end{array}$ & $\begin{array}{l}1.5^{* *} \\
(0.2)\end{array}$ & $\begin{array}{l}1.0^{* *} \\
(0.2)\end{array}$ & $\begin{array}{l}1.1^{\text {** }} \\
(0.2)\end{array}$ & $\begin{array}{c}0.2 \\
(0.2)\end{array}$ \\
\hline Other inactive & $\begin{array}{l}1.9^{* *} \\
(0.2) \\
\end{array}$ & $\begin{array}{c}2.0^{* *} \\
(0.3)\end{array}$ & $\begin{array}{l}1.2^{* *} \\
(0.2) \\
\end{array}$ & $\begin{array}{l}0.5^{\text {** }} \\
(0.2) \\
\end{array}$ & $\begin{array}{c}2.4^{* *} \\
(0.2) \\
\end{array}$ & $\begin{array}{c}2.1^{* *} \\
(0.2) \\
\end{array}$ & $\begin{array}{l}1.7^{\star *} \\
(0.2) \\
\end{array}$ & $\begin{array}{c}0.6^{* *} \\
(0.2) \\
\end{array}$ \\
\hline
\end{tabular}

Source: Author's calculations using EFF 2002 and data from the SCF 2001 included in the LWS database.

(1) The income-poverty line is set equal to 50 percent of the median equivalent household gross income, while the asset-poverty threshold is equal to one fourth of income-poverty line. The main results do not change when alternative thresholds are used. The reference household is a household with a white male head between 36 and 50 years who lives with his spouse and without children, and where the head is working, with a medium educational level. (2) This information is not available in the Spanish survey. (3) We consider children every household member below 15 years of age. (4) Educational levels are defined according to the International Standard Classification of Education designed by UNESCO described in the appendix. (5) * and ** indicate that the estimates are significant at $5 \%$ and $1 \%$, respectively. 
Table 7

Distribution of households by sex, age, and living arrangements in Spain and the U.S

\begin{tabular}{|c|c|c|c|c|}
\hline & \multicolumn{2}{|c|}{ Spain } & \multicolumn{2}{|c|}{ U.S. } \\
\hline & $\%$ & $\mathrm{~N}$ & $\%$ & $\mathrm{~N}$ \\
\hline All & 100 & 5,143 & 100 & 4,442 \\
\hline \multicolumn{5}{|l|}{ Household type } \\
\hline Age $<=25$ & 2.0 & 103 & 7.1 & 315 \\
\hline Non-single & 1.5 & 77 & 3.1 & 137 \\
\hline Single, male & 0.2 & 10 & 1.9 & 83 \\
\hline Single, female & 0.3 & 16 & 2.2 & 96 \\
\hline Age $(25,35]$ & 14.2 & 730 & 17.4 & 773 \\
\hline Non-single, no-kids (1) & 5.1 & 264 & 3.6 & 159 \\
\hline Non-single, kids & 7.1 & 364 & 7.4 & 329 \\
\hline Single, male & 1.0 & 50 & 2.3 & 104 \\
\hline Single, female, no-kids & 0.7 & 38 & 1.7 & 74 \\
\hline Single, female, kids & 0.3 & 15 & 2.4 & 107 \\
\hline Age $(35,50]$ & 32.5 & 1,673 & 34.0 & 1,511 \\
\hline Non-single, no-kids & 11.1 & 571 & 9.7 & 429 \\
\hline Non-single, kids & 17.6 & 905 & 13.9 & 619 \\
\hline Single, male & 1.8 & 92 & 3.9 & 175 \\
\hline Single, female, no-kids & 1.2 & 63 & 3.7 & 165 \\
\hline Single, female, kids & 0.8 & 41 & 2.8 & 122 \\
\hline Age $(50,65)$ & 23.7 & 1,218 & 20.4 & 905 \\
\hline Non-single & 21.6 & 1,111 & 14.0 & 623 \\
\hline Single, male & 1.1 & 55 & 2.5 & 112 \\
\hline Single, female & 1.0 & 52 & 3.8 & 170 \\
\hline Age $>=65$ & 27.6 & 1,419 & 21.1 & 938 \\
\hline Non-single & 19.3 & 990 & 11.3 & 502 \\
\hline Single, male & 1.7 & 88 & 2.8 & 123 \\
\hline Single, female & 6.6 & 340 & 7.0 & 313 \\
\hline
\end{tabular}

Source: Author's calculations using EFF 2002 and data from the SCF 2001 included $n$ the LWS database.

(1) We consider children every household member below 15 years of age. 
Table 8

Decomposition of the poverty rate difference between Spain and the U.S.(1)

(all variables in percentage)

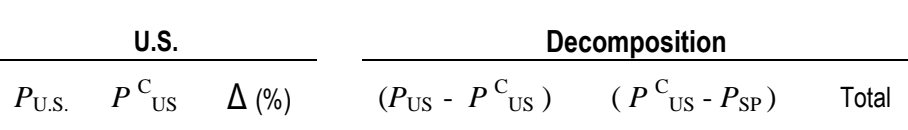

Classification 1: 19 sub-groups Income and Net worth

Twice-poor

Protected-poor

Vulnerable- non poor

$\begin{array}{ccc}9.9 & 6.5 & -34.2 \\ 13.4 & 13.7 & -0.9 \\ 7.7 & 5.1 & -33.4\end{array}$

45.9

54.1

100

Income and Non-housing wealth

Twice-poor

Protected-poor

Vulnerable- non poor

55.7

44.3

100

$5.1-33.4$

13.5

100

$\begin{array}{ccc}12.5 & 9.2 & -26.5 \\ 10.8 & 10.6 & -1.8 \\ 10.7 & 8.1 & -24.8\end{array}$

58.1

41.9

100

10.7

10.4

89.6

100

$-57.9$

157.9

100

Classification 2: 12 sub-groups

Income and Net worth

Twice-poor

Protected-poor

Vulnerable- non poor

Income and Non-housing wealth

\begin{tabular}{lcccccc} 
Twice-poor & 12.5 & 9.1 & -26.8 & 58.7 & 41.3 & 100 \\
Protected-poor & 10.8 & 10.5 & -2.1 & 12.2 & 87.8 & 100 \\
Vulnerable- non poor & 10.7 & 8.2 & -23.3 & -54.3 & 154.3 & 100 \\
\hline
\end{tabular}

Source: Author's calculations using EFF 2002 and data from the SCF 2001 included $n$ the LWS database.

(1) Poverty rates computed assuming an income-poverty line equal to 50 percent of the median equivalent household gross income, while the asset-poverty threshold is equal to one fourth of income-poverty line. The main conclusions hold when alternative thresholds are used.

(2) Classification 1 corresponds to the one presented in Table 7. Alternatively, for the second classification we consider five age groups: under 25, 25-35, 35-50, 50-65 and over 65. The household types we use to divide the population are single, non-single for those below 25 and those above 65 ; and non-single, single with children, and single without children for middle age groups. 
Table 9

The role of the household structure varying one household type at a time ${ }^{(1)}$ (all variables in percentage)

\begin{tabular}{|c|c|c|c|c|c|c|}
\hline & \multicolumn{6}{|c|}{$\Delta=\left(P_{\text {US }}^{\mathrm{C}}-P_{\text {U.S. }}\right) / P_{\text {U.S. }}$} \\
\hline & \multicolumn{3}{|c|}{ Income and Net worth } & \multicolumn{3}{|c|}{ Income and Non-housing wealth } \\
\hline & $\begin{array}{l}\text { Twice- } \\
\text { poor }\end{array}$ & $\begin{array}{l}\text { Protected } \\
\text { poor }\end{array}$ & $\begin{array}{l}\text { Vulnerable } \\
\text { non-poor }\end{array}$ & $\begin{array}{l}\text { Twice- } \\
\text { poor }\end{array}$ & $\begin{array}{l}\text { Protected } \\
\text { poor }\end{array}$ & $\begin{array}{l}\text { Vulnerable } \\
\text { non-poor }\end{array}$ \\
\hline$P_{\text {U.S. }}$ & 9.9 & 13.4 & 7.7 & 12.5 & 10.8 & 10.7 \\
\hline \multicolumn{7}{|l|}{$\Delta$ by household type } \\
\hline \multicolumn{7}{|l|}{ Age $<=25$} \\
\hline Non-single & -2.3 & -0.9 & -4.4 & -1.8 & -1.1 & -3.7 \\
\hline Single, male & -3.2 & -1.8 & -7.1 & -2.8 & -1.9 & -5.1 \\
\hline Single, female & -10.2 & -1.5 & -4.3 & -8.1 & -1.9 & -3.1 \\
\hline \multicolumn{7}{|l|}{ Age $(25,35]$} \\
\hline Non-single, no-kids (2) & 0.7 & 0.2 & 2.5 & 0.6 & 0.3 & 2.3 \\
\hline Non-single, kids & -0.4 & -0.3 & -0.6 & -0.4 & -0.2 & -0.8 \\
\hline Single, male & -0.5 & -0.8 & -3.4 & -0.5 & -0.8 & -2.3 \\
\hline Single, female, no-kids & -1.0 & -0.3 & -4.0 & -0.8 & -0.3 & -3.3 \\
\hline Single, female, kids & -9.8 & -3.4 & -3.6 & -8.3 & -3.7 & -3.2 \\
\hline \multicolumn{7}{|l|}{ Age $(35,50]$} \\
\hline Non-single, no-kids & 1.0 & 0.6 & 0.9 & 1.0 & 0.4 & 1.0 \\
\hline Non-single, kids & 2.1 & 2.8 & 1.2 & 2.5 & 2.5 & 2.3 \\
\hline Single, male & -2.2 & -0.8 & -2.5 & -1.8 & -0.9 & -3.0 \\
\hline Single, female, no-kids & -1.7 & -2.4 & -5.9 & -2.3 & -1.9 & -4.7 \\
\hline Single, female, kids & -5.2 & -2.4 & -3.1 & -4.7 & -2.3 & -2.7 \\
\hline \multicolumn{7}{|l|}{ Age $(50,65)$} \\
\hline Non-single & 2.0 & 5.6 & 3.2 & 3.0 & 5.3 & 4.0 \\
\hline Single, male & -1.9 & -1.8 & -0.8 & -1.8 & -1.8 & -1.0 \\
\hline Single, female & -3.2 & -3.9 & -1.9 & -2.8 & -4.5 & -1.8 \\
\hline \multicolumn{7}{|l|}{ Age $>=65$} \\
\hline Non-single & 2.6 & 12.6 & 1.1 & 3.8 & 13.6 & 0.8 \\
\hline Single, male & -0.9 & -1.6 & -0.2 & -1.0 & -1.6 & -0.7 \\
\hline Single, female & -0.7 & -1.2 & 0.01 & -0.9 & -1.2 & -0.1 \\
\hline
\end{tabular}

Source: Author's calculations using EFF 2002 and data from the SCF 2001 included in the LWS database.

(1) The income poverty line is set equal to 50 percent of the median equivalent household gross income, while the asset-poverty threshold is equal to one fourth of income-poverty line. The main conclusions do not change when alternative thresholds are used.

(2) We consider children every household member below 15 years of age. 
Table A.1

Information included in the EFF 2002 and the in the LWS database from the SCF 2001 ( $A=$ available)

\begin{tabular}{|c|c|c|c|c|}
\hline & \multicolumn{2}{|c|}{ EFF 2002} & \multicolumn{2}{|c|}{ SCF 2001} \\
\hline & Ownership & Value & Ownership & Value \\
\hline \multicolumn{5}{|l|}{ Real assets } \\
\hline Principal residence & $A$ & $A$ & A & A \\
\hline Other real estate & $A$ & $A$ & A & $A$ \\
\hline Vehicles & A & $A$ & A & A \\
\hline Business equities & A & $A$ & A & A \\
\hline Durables and Collectibles ${ }^{(1)}$ & A & A & A & A \\
\hline \multicolumn{5}{|l|}{ Financial assets } \\
\hline Saving and deposits & $A$ & $A$ & A & A \\
\hline Fixed income securities & A & $A$ & A & A \\
\hline Mutual funds & $A$ & $A$ & A & A \\
\hline Shares & A & $A$ & $A$ & A \\
\hline Private pension schemes & A & $A$ & A & A \\
\hline Life Insurance & A & $A$ & A & $A$ \\
\hline Other financial assets & A & A & A & A \\
\hline \multicolumn{5}{|l|}{ Debts } \\
\hline Principal residence & A & $A$ & A & A \\
\hline Other real state properties & A & A & A & A \\
\hline Vehicles and educational loans & $A$ & $A$ & A & A \\
\hline Other debts & A & $A$ & A & A \\
\hline
\end{tabular}

Source: Author's calculations using EFF 2002 and data from the SCF 2001 included in the LWS database. 


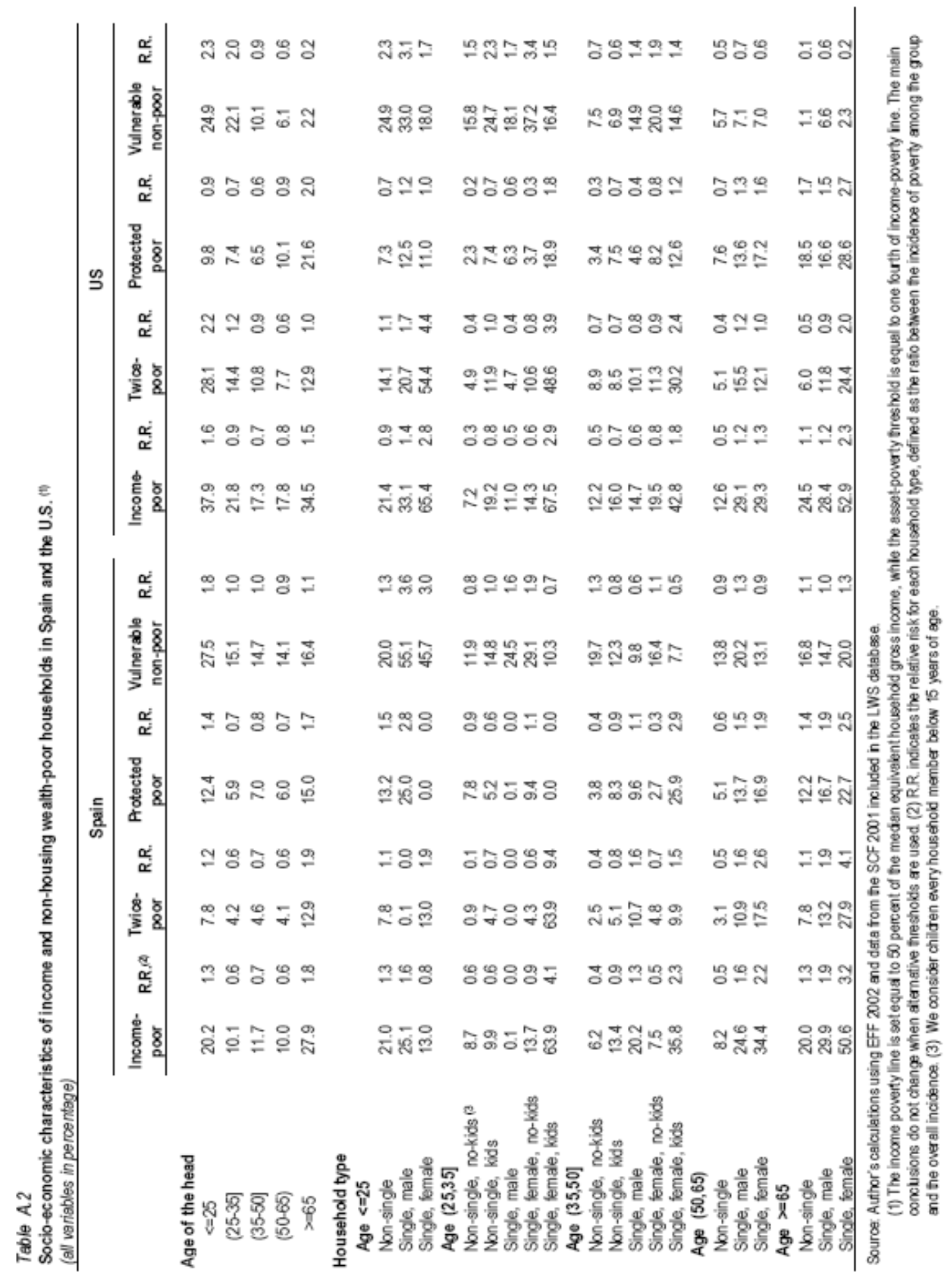


Table A.3

Regression on the probability of income and non-housing wealth-poverty in Spain and the U.S. (1) (standard errors in parenthesis)

Constant

Age, sex, and race of the head

$<=25$

$(25-35]$

$(50-65]$

$(65-75]$

$>75$

Female

Non white (2)

Household type

Size

Size ${ }^{\wedge} 2$

Single

Lone parent

Couple with children (3)

Education and

Labour status (4)

\begin{tabular}{|c|c|c|c|c|c|c|c|c|}
\hline Low educated head & $\begin{array}{l}1.0^{* *} \\
(0.2)\end{array}$ & $\begin{array}{l}0.9^{* *} \\
(0.2)\end{array}$ & $\begin{array}{l}0.7^{\text {** }} \\
(0.1)\end{array}$ & $\begin{array}{c}0.5^{\text {** }} \\
(0.1)\end{array}$ & $\begin{array}{l}1.3^{* *} \\
(0.1)\end{array}$ & $\begin{array}{l}1.4^{* *} \\
(0.1)\end{array}$ & $\begin{array}{l}0.6^{* *} \\
(0.1)\end{array}$ & $\begin{array}{l}0.3^{*} \\
(0.2)\end{array}$ \\
\hline High educated head & $\begin{array}{c}-0.7^{*} \\
(0.3)\end{array}$ & $\begin{array}{l}-0.4 \\
(0.3)\end{array}$ & $\begin{array}{c}-0.5^{* *} \\
(0.2)\end{array}$ & $\begin{array}{c}-0.5^{* *} \\
(0.2)\end{array}$ & $\begin{array}{c}-1.1^{\text {** }} \\
(0.2)\end{array}$ & $\begin{array}{c}-0.9^{* *} \\
(0.1)\end{array}$ & $\begin{array}{c}-0.8^{* *} \\
(0.1)\end{array}$ & $\begin{array}{c}-0.7^{\text {** }} \\
(0.1)\end{array}$ \\
\hline Unemployed & $\begin{array}{l}1.9^{* *} \\
(0.2)\end{array}$ & $\begin{array}{l}1.7^{\text {**}} \\
(0.2)\end{array}$ & $\begin{array}{l}1.4^{* *} \\
(0.2)\end{array}$ & $\begin{array}{l}0.8^{* *} \\
(0.2)\end{array}$ & $\begin{array}{l}1.2^{\text {** }} \\
(0.2)\end{array}$ & $\begin{array}{l}1.4^{* *} \\
(0.2)\end{array}$ & $\begin{array}{l}0.7^{\text {** }} \\
(0.2)\end{array}$ & $\begin{array}{c}0.8^{* *} \\
(0.2)\end{array}$ \\
\hline Retired & $\begin{array}{l}0.9^{* *} \\
(0.2)\end{array}$ & $\begin{array}{l}0.9^{* *} \\
(0.2)\end{array}$ & $\begin{array}{l}0.4^{* *} \\
(0.2)\end{array}$ & $\begin{array}{c}0.1 \\
(0.2)\end{array}$ & $\begin{array}{l}1.5^{\text {** }} \\
(0.2)\end{array}$ & $\begin{array}{l}1.1^{* *} \\
(0.2)\end{array}$ & $\begin{array}{l}1.0^{* *} \\
(0.2)\end{array}$ & $\begin{array}{c}0.1 \\
(0.2)\end{array}$ \\
\hline Other inactive & $\begin{array}{l}1.9^{* *} \\
(0.2)\end{array}$ & $\begin{array}{l}1.9^{* *} \\
(0.2)\end{array}$ & $\begin{array}{c}1.0^{* *} \\
(0.2)\end{array}$ & $\begin{array}{l}0.5^{\text {** }} \\
(0.2)\end{array}$ & $\begin{array}{c}2.4^{* *} \\
(0.2)\end{array}$ & $\begin{array}{c}2.2^{* *} \\
(0.2)\end{array}$ & $\begin{array}{l}1.5^{* *} \\
(0.2)\end{array}$ & $\begin{array}{l}0.5^{*} \\
(0.2)\end{array}$ \\
\hline
\end{tabular}

Source: Author's calculations using EFF 2002 and data from the SCF 2001 included in the LWS database.

(1) The income poverty line is set equal to 50 percent of the median equivalent household gross income, while the asset-poverty threshold is equal to one fourth of income-poverty line. The main conclusions do not change when alternative thresholds are used. The reference household is a household with a white male head between 36 and 50 years who lives with his spouse and without children, and where the head is working, with a medium educational level. (2) This information is not available in the Spanish survey. (3) We consider children every household member below 15 years of age. (4) Educational levels are defined according to the International Standard Classification of Education designed by UNESCO described in the appendix. (5) * and ** indicate that the estimates are significant at $5 \%$ and $1 \%$, respectively. 
Table A.4

Socio-economic characteristics of households in Spain and the U.S. (1) (all variables indicate percentage of households)

\begin{tabular}{|c|c|c|}
\hline & Spain & U.S. \\
\hline All & 100 & 100 \\
\hline $\begin{array}{l}\text { Age, sex, race and mar } \\
\text { status of the head } \\
<=25 \\
(25-35] \\
(35-50] \\
(50-65] \\
(65-75] \\
>75\end{array}$ & $\begin{array}{c}2.0 \\
14.2 \\
32.5 \\
25.7 \\
16.6 \\
9.0\end{array}$ & $\begin{array}{c}7.1 \\
17.4 \\
34.0 \\
21.4 \\
11.1 \\
9.0\end{array}$ \\
\hline $\begin{array}{l}\text { Male } \\
\text { Female }\end{array}$ & $\begin{array}{l}66.1 \\
33.9\end{array}$ & $\begin{array}{l}45.6 \\
54.5\end{array}$ \\
\hline $\begin{array}{l}\text { White (1) } \\
\text { Non white }\end{array}$ & & $\begin{array}{l}53.5 \\
46.5\end{array}$ \\
\hline $\begin{array}{l}\text { Married } \\
\text { Divorced } \\
\text { Widowed } \\
\text { Never married }\end{array}$ & $\begin{array}{c}71.2 \\
5.1 \\
12.6 \\
11.1\end{array}$ & $\begin{array}{c}53.1 \\
18.3 \\
9.4 \\
19.3\end{array}$ \\
\hline $\begin{array}{l}\text { Household type } \\
\text { Single } \\
\text { Lone parent } \\
\text { Couple, with children (2) } \\
\text { Couple, without children }\end{array}$ & $\begin{array}{c}15.5 \\
1.2 \\
55.1 \\
28.2\end{array}$ & $\begin{array}{c}30.6 \\
9.7 \\
33.0 \\
26.7\end{array}$ \\
\hline $\begin{array}{l}\text { Household size } \\
1 \\
2 \\
3 \\
4 \\
5 \text { and more }\end{array}$ & $\begin{array}{l}15.2 \\
25.7 \\
24.3 \\
24.3 \\
10.6\end{array}$ & $\begin{array}{c}28.6 \\
35.6 \\
14.2 \\
12.9 \\
8.8\end{array}$ \\
\hline $\begin{array}{l}\text { Number of children } \\
0 \\
1 \\
2 \\
3 \text { or more }\end{array}$ & $\begin{array}{c}70.6 \\
17.5 \\
10.5 \\
1.4\end{array}$ & $\begin{array}{c}67.9 \\
14.5 \\
11.9 \\
5.7\end{array}$ \\
\hline $\begin{array}{l}\text { Labour status and Educ } \\
\text { of the head }(3) \\
\text { Working } \\
\text { Unemployed } \\
\text { Retired } \\
\text { Other inactive }\end{array}$ & $\begin{array}{c}57.1 \\
5.1 \\
25.4 \\
12.5\end{array}$ & $\begin{array}{c}71.7 \\
3.4 \\
18.0 \\
7.0\end{array}$ \\
\hline $\begin{array}{l}\text { Low } \\
\text { Medium } \\
\text { High }\end{array}$ & $\begin{array}{l}59.2 \\
25.7 \\
15.1\end{array}$ & $\begin{array}{l}12.1 \\
57.9 \\
30.0\end{array}$ \\
\hline
\end{tabular}

Source: Author's calculations using EFF 2002 and data from the SCF 2001 included n the LWS database.

(1) This information is not available in the Spanish survey.

(2) We consider children every household member below 15 years of age.

(3) Educational levels are defined according to the International Standard Classification of Education designed by UNESCO. 